Discussion

Papers

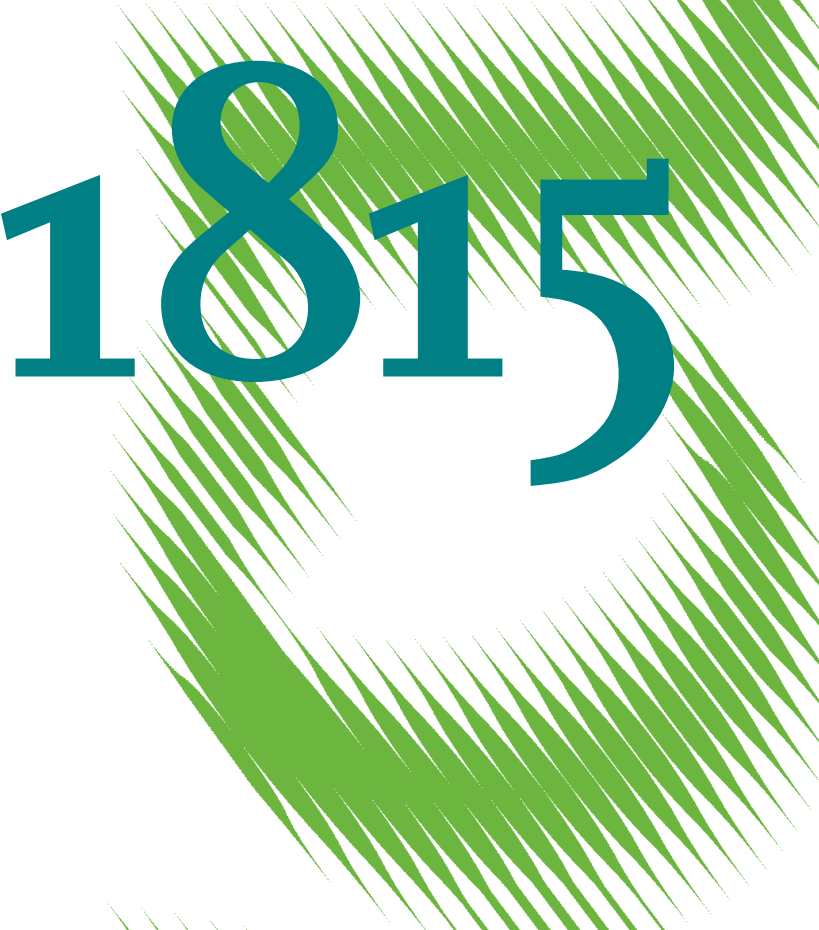

Long Run Effects of Universal Childcare on Personality Traits 
Opinions expressed in this paper are those of the author(s) and do not necessarily reflect views of the institute.

IMPRESSUM

(C) DIW Berlin, 2019

DIW Berlin

German Institute for Economic Research

Mohrenstr. 58

10117 Berlin

Tel. +49 (30) $89789-0$

Fax +49 (30) $89789-200$

http://www.diw.de

ISSN electronic edition 1619-4535

Papers can be downloaded free of charge from the DIW Berlin website:

http://www.diw.de/discussionpapers

Discussion Papers of DIW Berlin are indexed in RePEc and SSRN:

http://ideas.repec.org/s/diw/diwwpp.html

http://www.ssrn.com/link/DIW-Berlin-German-Inst-Econ-Res.html 


\title{
Long Run Effects of Universal Childcare on Personality Traits ${ }^{\text {ts }}$
}

\author{
Maximilian Bach*, Josefine Koebe, Frauke Peter \\ DIW Berlin
}

June 4, 2019

\begin{abstract}
Although universal childcare has become an essential tool to support child development, few economic studies analyze its effects on non-cognitive skills and little is known about causal effects on these skills in the long run. In this paper we go beyond short run analyses and examine the long run effects of one additional year of universal childcare on students' personality traits in adolescence. We focus on personality traits as part of their non-cognitive skills set and as important predictors of later educational achievements. As of 1996, a legal entitlement to universal childcare applied to children of three years and older in Germany. However, severe shortages in the former-West meant that many children could not get a childcare place and had to wait a full year until the next entry date. Using data from the National Educational Panel Study (NEPS) we estimate effects of one additional year of childcare by exploiting geographical variation in the timing of childcare entry arising from local supply constraints. We find that an earlier entry in universal childcare increases extroversion in adolescence, which has been shown to be associated with favorable labor market outcomes.
\end{abstract}

Keywords: early childcare, non-cognitive skills, personality traits JEL: I21, J13, J18, J24

\footnotetext{
${ }^{3}$ We are thankful for helpful comments from Bernd Fitzenberger, Jan Marcus, Pamela Meyerhofer, Hessel Oosterbeek, Erik Plug, Birgitta Rabe, C. Katharina Spiess, Sevrin Waights, Felix Weinhardt, and from seminar participants at DIW Berlin, the University of Amsterdam as well as to participants at the 3rd Annual Meeting of BIEN 2016, at the LEER Workshop on Education Economics 2017 at KU Leuven, at the Spring Meeting of Young Economists 2017 in Halle, at the annual meeting of the ESPE 2017 in Glasgow, of the IWAEE 2017 in Catanzaro, of the Verein für Socialpolitik 2017 in Vienna, and of the EALE 2017 in St. Gallen. Frauke Peter gratefully acknowledges funding from the German Ministry of Education and Research which provided funding for the project: "Nicht-monetäre Erträge von Bildung in den Bereichen Gesundheit, nicht-kognitive Fähigkeiten sowie gesellschaftliche und politische Partizipation". We thank Adam Lederer for very helpful editorial assistance. An earlier version of this paper circulated under the title 'Early Childcare Entrance and Personality Traits'.

This paper uses data from the National Educational Panel Study (NEPS): Starting Cohort Grade 9, doi:10.5157/NEPS:SC4:7.0.0. From 2008 to 2013, NEPS data was collected as part of the Framework Program for the Promotion of Empirical Educational Research funded by the German Federal Ministry of Education and Research (BMBF). As of 2014, NEPS is carried out by the Leibniz Institute for Educational Trajectories (LIfBi) at the University of Bamberg in cooperation with a nationwide network. This paper uses confidential microdata from the NEPS (see disclaimer above). They can be accessed based on the terms and conditions of the research data center of the Leibniz Institute for Educational Trajectories (LIfBi): https://www.nepsdata.de/tabid/296/language/en-US. The authors are willing to provide guidance on how to acquire the data (mbach@diw.de). The usual disclaimer applies.

${ }^{*}$ Corresponding author

Email addresses: mbach@diw.de (Maximilian Bach), jkoebe@diw.de (Josefine Koebe), fpeter@diw.de
} (Frauke Peter) 


\section{Introduction}

Universal provision of childcare has become an essential policy tool to both increase parental employment opportunities and support child development in many European countries. The aim of this study is to better understand the effects of universal childcare attendance on personality traits as part of the non-cognitive skill set in adolescence, with a particular focus on childcare entry age, in other words, years spent in childcare. Specifically, we analyze if entering childcare at the age of three compared to the age of four and subsequently attending childcare for three years versus two years affect students' personality traits at age fifteen. We exploit variation in the access to childcare in the mid-1990s in the western federal states of Germany. The three main contributions of this study are (1) long run outcomes, (2) a focus on personality traits as important skills for educational and labor market success, and (3) that we can address the selection bias of childcare attendance with an instrumental variable (IV) approach bearing crucial policy implications.

This paper is closely related to previous work on the effects of universal childcare provision on children's cognitive and non-cognitive skills. Yet, previous results in the economic literature are diverse because they vary in how and to whom childcare services are provided. Most studies simply look at the effects of attending versus not attending. Given that in the European context nearly all children above the age of three attend childcare today, the current literature examines more refined measures of childcare enrollment, such as entrance age, duration of childcare, or dosage of childcare, i.e. half day versus full day attendance (e.g Loeb et al., 2007; Müller et al., 2013; Peter et al., 2016). In this paper, we further contribute to this strand of the literature by analyzing the causal effect of early childcare entrance, the effect of one additional year of childcare, on personality traits in the long run. Looking at long-run outcomes requires us to carefully assess the institutional landscape at the time of the exposure to the treatment in the former-West of Germany. Whereas today early attendance might start at age one, two decades ago starting childcare early in western Germany typically meant entering childcare at the age of three or later.

We focus on adolescent's personality traits, since they are important predictors of later educational achievements, health outcomes, and labor market success (e.g Fletcher, 2013; Blanden et al., 2007; Brunello and Schlotter, 2011; Baron and Cobb-Clark, 2010; Heckman et al., 2013; Caliendo et al., 2015; Prevoo and ter Weel, 2015). ${ }^{1}$ The development of skills and the level of non-cognitive skills in adolescence are of particular social relevance. This period of transition from childhood to adulthood marks a critical point in the life course as well as

\footnotetext{
${ }^{1}$ For an overview of the economic literature on the effect of childcare on non-cognitive skills, see the summary of Camehl (2016).
} 
for the development of the adult personality. It is the time when adolescents make decisions about further education and transitions to the labor market, having lasting implications for both labor market returns and performance. So far, few economic studies focus on the effects of universal childcare on non-cognitive skills in adolescence, although Heckman et al. (2013) show for the Perry Preschool intervention in the U.S. that non-cognitive skills explain more of the variance in later outcomes than cognitive skills. The same is true for findings from another U.S. intervention, project STAR, a kindergarden class size experiment for children at age five which also reveals a long run causal impact on non-cognitive skills (Chetty et al., 2011; Bietenbeck, 2019). All the same, these results cannot necessarily be transferred to universal childcare services as findings show from Norway and the Canadian province of Quebec (Havnes and Mogstad, 2011; Baker et al., 2019).

To identify the causal effect of early childcare attendance on long-run personality development we utilize county-level variation in childcare slots during the mid-1990s in the western federal states in Germany. At that time, childcare attendance rates of children above three were substantially lower than today: In 1991, only 33\% of three-year-olds attended childcare in the western German federal states (see Figure 1) compared to $94 \%$ in 2018 (Jessen et al., 2018). In the mid-1990s, the German government introduced a legal claim to a childcare slot for children aged three and older. Implementation of the reform took place at the county level. Western German counties faced difficulties providing enough universal childcare slots, as the demand for childcare exceeded the number of available places. The provision of childcare slots remained difficult until the early 2000s, resulting in varying shortages across counties and, to some extent, differing admission rules.

We use these geographical differences in universal childcare provision as an instrument for determining early entry into childcare. This method has also been used by Datta Gupta and Simonsen (2010) who exploit variations in demand for childcare provision in Denmark to compare two types of childcare and their influence on non-cognitive skills at the age of eleven. Furthermore, Felfe and Lalive (2018) use a marginal treatment effects framework with administrative data of one western German federal state, Schleswig-Holstein, finding that causal effects vary with observed characteristics for short-run outcomes. In addition, Cornelissen et al. (2018) exploit the reform of a legal claim in 1996 using administrative data on school readiness (measured at age six) of one particular region in one federal state, West-Ems region in Lower-Saxony, in western Germany. They find that children who are likely to benefit the most from childcare, children from low-income families, are less likely to attend childcare early.

It is ex ante unclear if and how one more year of childcare attendance affects students' personality traits in terms of their non-cognitive skills set. There may be both negative and 
positive effects. One additional year of childcare attendance may lead to an increase in certain personality traits. However, a personality traits set that puts high weight on agreeableness, for example, may not be advantageous for adolescents' educational decision making process. Entering childcare early may also decrease personality traits. For example, a personality trait set with lower weight on being conscientious may lead to lower educational or labor market outcomes. Studies in the economic literature show an increase in the likelihood of transiting to secondary schooling, college graduation, and higher wages for individuals with trait sets 'emphasizing' openness, conscientiousness, or extroversion (Mueller and Plug, 2006; Borghans et al., 2008; Baron and Cobb-Clark, 2010; Heineck and Anger, 2010; Almlund et al., 2011; Lundberg, 2013; Fletcher, 2013). Looking at findings from the literature on short run childcare effects on non-cognitive skills, Peter et al. (2016) show that children in England who enter childcare early are more prosocial and experience fewer peer problems at the age of five and seven. Given that children in childcare more frequently interact with other peers and adults than they would have when not attending, we hypothesize that one additional year of universal childcare attendance might most likely affect the level of students' personality trait dimensions extroversion and openness to new experience in the long run. Furthermore, we hypothesize that attending childcare earlier might also affect students' conscientiousness in the long run since attending childcare implies a daily routine as well as the necessity to share with others and to be respectful.

We use data on students born between 1994 and 1996 from the German National Educational Panel Study (NEPS) (Blossfeld et al., 2011) for whom the exact starting date of universal childcare can be observed. In total, we analyze data of more than 4,500 students who attend the ninth grade in 2010 at the age of 15 . We construct a binary variable measuring earlier childcare entrance, which is also equivalent to longer childcare duration. We code all students who started childcare around the childcare entry date in the year they turned three (which coincides with the beginning of the school year in August or September) as one and students entering childcare approximately one year later (in the year they turn four) as zero. To address potential endogeneity concerns from omitted variable bias or reverse causality we complement the NEPS data with administrative data at the county level. We use information on the slot-child-ratio for three to six and a half year old children at the county level which comprises the ratio of available childcare places over the number of children in that age group. In the institutional context of severe rationing despite a legal claim for all children above three even newly created slots are immediately filled due to excess demand. Hence, the slot-child-ratio measures the county supply as well as the attendance rate in the former-West of Germany. A high slot-child-ratio indicates a region with more supply of childcare places, a low ratio signals the opposite. We calculate the slot-child-ratio for the western German 
counties in 1994 and 1998 using data provided by the research data center (RDC) of the federal statistical office and the statistical offices of the federal states ('Länder'), namely the statistics of children and youth welfare ('Kinder- und Jugendhilfestatistik') (Statistisches Bundesamt, 2013).

We find that attending universal childcare affects personality traits of students in ninth grade at age fifteen. Our results suggest a sizable increase of $0.37 \mathrm{SD}$ in the personality trait extroversion for children who are induced to enter childcare one year earlier because of a larger supply of childcare places in their county. This result is robust against the inclusion of a rich set of family background and regional characteristics. In addition, we estimate the effect of early childcare entry on arguably pre-determined outcomes of children. These are height at adolescence, low birth weight, and premature birth. For all three outcomes we find no effects of entering childcare earlier. This makes us confident that the slot-childratio is 'exogenous' to any other factors influencing students' extroversion. For the other personality trait dimensions we observe a rather mixed pattern of results. To further probe the robustness of our results, we cross validate our results with a comparable, representative sample of slightly older students from the German Socio-Economic Panel Study (SOEP). These data allow to control for a more extensive set of family characteristics, including parents' personality traits, but include considerably fewer observations. Reassuringly, we find a similar effect on extroversion in the SOEP data, corroborating the results from the NEPS.

In this study we build on and extend the existing literature in at least three important directions. First, we look at long-run outcomes. So far, the economic literature has mainly shown short-run effects of childcare attendance on cognitive and non-cognitive skills (amongst others Magnuson et al., 2007; Loeb et al., 2007; Baker et al., 2008; Berlinski et al., 2009; Brilli et al., 2011; Datta Gupta and Simonsen, 2010, 2012; Drange et al., 2016; Peter et al., 2016). Fewer studies analyze the causal effect of universal childcare on outcomes in the medium or long run, looking at educational attainment, income, or the need for social assistance (e.g. Dumas and Lefranc, 2010; Havnes and Mogstad, 2011; Apps et al., 2013; DeCicca and Smith, 2013; Fessler and Schneebaum, 2016; Kuehnle and Oberfichtner, 2017; Baker et al., 2019). Second, our focus lies on personality traits and childcare attendance, specifically early entrance. Personality traits, as part of the non-cognitive skills set, have received less attention in the childcare literature, in particular as an outcome. Yet, many studies now demonstrate the predictive power of these skills for relevant life outcomes such as educational attainment and labor market success (Heckman et al., 2006). There is also a growing literature showing that these skills may be fostered early and in institutional settings, i.e. childcare centers (Kautz et al., 2014). And third, our IV approach overcomes several selection or potential 
reverse causality concerns that might bias OLS estimates of early entry into childcare on personality traits in adolescence.

The remainder of the paper is structured as follows: Section 2 describes the institutional setting. Section 3 outlines the empirical strategy and Section 4 describes the data in more detail. This is followed by the results in Section 5 and further analyses in Section 6. Section 7 presents several robustness tests before Section 8 concludes.

\section{Institutional Background}

In this paper, we examine the potential long-run effect of attending childcare for one additional year using the county-level variation in childcare slots during the mid-1990s. We restrict our analysis to the western federal states of Germany, since the institutional setting of former-East Germany guaranteed almost full provision of childcare for all children from age one until school start (see Figure 1 for a comparison of attendance rates between West and East Germany in the 1990s). As childcare was a key pillar of socialistic policy and thus former-East Germany also differs in norms and values, especially with respect to childcare, which makes it more difficult to compare to former-West Germany in this context. We focus on children aged three years and older who attend universal childcare also known under the widespread term "Kindergarten". Whereas kindergarden in the United States starts elementary school and aims at five year old children, the German "Kindergarten" comprises both care and education in institutions for children of age three and older (until school starting age which most children enter at age six in Germany) in mainly age-mixed groups. The U.S. counterpart to the German "Kindergarten" would be pre-school instead. In comparison, the German universal childcare system comprises on average higher quality care and nearly all childcare institutions are publicly funded, leaving little market power for private suppliers (Spiess, 1998; Kreyenfeld and Hank, 2000).

Public involvement in the childcare system in western Germany in the 1990s was mainly driven by educational motivations along with the ambition to provide equal opportunities for all children. However, childcare slots were severely rationed and free places were mainly granted to older children (Spiess, 2008; Alt et al., 2018). Thus, childcare attendance varied substantially by age, as shown in Figure 1. In 1991, only 33 percent of all three-year-old and 70 percent of all four-year-old children attended formal childcare in western Germany. One of the first "milestone" reforms to roll out the universal childcare system for all children aged three or older was implemented through the introduction of a legal right to a slot in highly

\footnotetext{
${ }^{2}$ In the 1970s, the "Kindergarten" was officially established as first stage of the German educational system (Deutscher Bildungsrat, 1970).
} 
subsidized half-day childcare. ${ }^{3}$ The law became effective in January 1996. ${ }^{4}$ Figure 1 shows that in the years after the reform childcare attendance rates for three-year-olds increased by more than 20 percentage points and around 15 percentage points for four-year-olds (see Figure 1), while the attendance rates for older children remained relatively stable. Hence, the roll-out of the German childcare system mainly affected younger children for whom excess demand had been largest.

[Figure 1 about here]

Whether or not parents of three year old children were able to claim their slot for which the 1996 reform had given them a legal right, depended on the local availability of childcare places in their county of residence. Figure 2 depicts the high level of regional variation in childcare supply in western Germany at the time. Some counties could provide slots for only 44 percent of the children in the relevant three to six years old age group (white areas in Fig. 2), while other counties had childcare provision rates exceeding 92 percent (black areas in Fig. 2). These large regional differences reflect the decentralized planning process of childcare provision in Germany. Under the subsidiarity principle, the smallest social unit is responsible for providing childcare services. ${ }^{5}$ In the context of the 1996 reform, this meant that even though the legal mandate originated at the federal level, states were responsible for the financial implementation and passed roll-out obligations onto the counties and municipalities.

[Figure 2 about here]

Since most counties were unable to meet the demand originating from the new law, children typically enrolled in childcare between August and September rather than around their third birthday. This is related to the systematic release of slots in childcare centers through school enrolment of school-aged children (typically at age six in Germany). ${ }^{6}$ However,

\footnotetext{
${ }^{3}$ Bauernschuster and Schlotter (2015) find that the expansion of universal childcare coverage after the 1996 reform increased the labour market participation of mothers with eligible children by 6.4 percentage points. However, given that the reform covered only half-day care, the economic aspect of facilitating maternal labor supply played a subordinated role. It became a primary policy goal of the roll-out of the childcare system for one- and two-year-olds later on (Kreyenfeld and Hank, 2000; Spiess, 2008).

${ }^{4}$ The legal claim for children aged three or older is anchored in §24 SGB VIII ("Achtes Sozialgesetzbuch") and the legal claim for children older than 12 months amended §24 SGB VIII and became effective on August $1,2013$.

${ }^{5}$ See Spiess (2008) for a detailed synopsis on the composition and organization of the German childcare system.

${ }^{6}$ Up until today, children typically enroll in childcare between August and September as school enrolment still frees up most capacities for new cohorts.
} 
in many counties not enough children vacated places to enroll all children turning three, who demanded a place under the legal claim. ${ }^{7}$ Hence, in most of the counties in the former-West with a shortage of supply, especially in the early years between 1996 and 1998, children did not get one of these slots in the year that they turned three. Instead, they had to wait nearly one year until they could enter childcare in August/September the next year.

Our empirical strategy uses this particular institutional landscape by instrumenting attending childcare at age three (according to the legal right) with the respective supply of childcare places in the county of residence. Since the specific planning process of municipalities in Germany leaves little room for parents to shape the regional supply of childcare (Kreyenfeld et al., 2001), this alleviates concerns that a higher provision of childcare in certain regions is potentially correlated with other factors affecting adolescent outcomes. In addition, regional mobility in Germany is low, reducing concerns that parents selectively move to counties with a higher childcare supply, which in turn could potentially bias our results. Regional net mobility patterns for the year 1996 among federal states also appear to be unrelated to childcare availability (see Figure A.1 in the Appendix). We further provide evidence that controlling for more or less conservative political preferences on the county level, which might affect regional childcare supply indirectly through anticipated voting behavior by politicians, does not alter our results.

In sum, at the time of legal entitlement for a slot in childcare at age three in 1996, the likelihood of actually starting childcare at this age was constrained by the local availability of places. These shortages varied considerably across regions because of the highly decentralized childcare system and it is this variation that we exploit in our estimation strategy.

\section{Empirical strategy}

To estimate the long run effects of an earlier entry into childcare and the years spend in childcare, we compare children from the same birth cohorts who entered childcare approximately one year apart. Early entrance is defined to take place two months around the official school entry month (which falls between August and September) of the year a child turns three (the legal entitlement age for a universal childcare slot at the time). We refer to these children who enter early as treatment group. Late entrance refers to children enrolling in childcare in the year they turn four (control group). Conditional on month of birth, children from these two groups differ by approximately one year in their childcare starting age. This is illustrated in Figure 3 where we plot childcare entry age against birth month

\footnotetext{
${ }^{7}$ For more institutional details on this so-called decisive decision rule of counties, which is related to children's birth month, see Bauernschuster and Schlotter (2015).
} 
for our sample. ${ }^{8}$ Data points clustered around the black solid lines correspond to children in the treatment group, and thus, to children who enter childcare in August or September in the year they turn three. Data points close to the dashed lines correspond to children from the control group. Figure 3 clearly shows that children in our sample typically enter childcare between August and September, when first-graders vacate universal childcare slots each year. For example, children born in January are often either 43-44 months old when they enter childcare in the year they turn three or 55-56 months when they enter one year later. Our definition of early and late childcare entry excludes some of those observations who cluster around the horizontal line at the age of 36 months. These are children who entered childcare as soon as they turned three, which was only possible in regions with a sufficient supply of childcare places. Excluding these children from the analyses allows us to maintain a one-year-interval in childcare starting age between treatment and control groups. ${ }^{9}$

[Figure 3 about here]

A simple comparison of personality traits across treatment and control groups may not yield the causal effect of early childcare entry because of potential selection effects. The primary concern is that age at childcare start is not only determined by the availability of places, but may depend to a large extent on family background characteristics. These characteristics are known to be important determinants of children's non-cognitive skills (for example, see Cunha and Heckman, 2007, 2008). In Germany, several family characteristics are associated with the timing of childcare entry, e.g. maternal employment status, single parenthood, or parental education. ${ }^{10}$ For instance, Büchel et al. (2002) point out that in the mid-1990s to early 2000s children from low socio-economic backgrounds with working mothers were prioritized, if childcare centers had insufficient places for three-year-old children. Whether these factors cause an upward or downward bias is ex ante not clear. Thus, our analysis includes a rich set of family background characteristics, among others, parental education, household income, maternal employment, household size, and single parenthood, to control for systematic differences across treatment and control groups. ${ }^{11}$

\footnotetext{
${ }^{8}$ For a detailed description of the data, see Section 4.

${ }^{9}$ Results including those children are qualitatively similar to our main results, but with somewhat smaller effects and increased standard errors because of a reduced difference in the average age at childcare entry between treatment and control groups.

${ }^{10}$ Büchner and Spiess (2007) find that maternal employment status is an important predictor of starting childcare at the age of three rather than at later ages. Labor supply of women is generally found to be positively affected by the level of their education (Schultz, 1990). On the other hand, maternal employment can result from poor employment opportunities for the husband (Juhn and Murphy, 1997) or single parenthood.

${ }^{11}$ See also Schober and Spiess (2013); Spiess and Büchner (2009) and Wrohlich (2008) for further research on determinants of childcare entry in Germany.
} 
However, other unobserved factors might exist that influence the timing of childcare entry and personality traits in adolescence. There is, for example, the possibility of reverse causality, i.e. a child's pre-existing personality traits (which we do not observe) might affect the timing of childcare entry. In that case simple OLS estimates are likely to be biased. Thus, we apply an instrumental variable approach that takes advantage of regional differences in the supply of childcare similar to the empirical strategy by Felfe and Lalive (2012), Felfe and Lalive (2018), and Cornelissen et al. (2018). ${ }^{12}$ The rationale behind this strategy is that the supply of childcare places in Germany varies considerably across regions and at the time was the main determinant for whether a child could enter childcare in the year she turns three or one year later. We assume that the factors determining the regional childcare supply are unlikely to be related to other determinants of children's development conditional on a rich set of control variables.

Hence, we use the conditional quasi-random assignment of available childcare places to estimate the causal effect of an early childcare entry on children's long-run personality traits. More specifically, we estimate the following linear model:

$$
\begin{aligned}
& C_{i}=\gamma Z_{i}+X_{i}^{\prime} \gamma+\epsilon_{i} \\
& Y_{i}=\beta C_{i}+X_{i}^{\prime} \delta+\eta_{i}
\end{aligned}
$$

where $Y_{i}$ is the personality trait measure of individual $i, X$ is a vector of controls that includes, among other things, birth month fixed effects, maternal employment status, household income, parental education. It further includes several regional characteristics that predict local childcare demand. ${ }^{13}$ To mitigate potential bias from misspecification, we rely on dummy variables for each category for all included variables in our regressions. This also allows us to deal with missing information in a straightforward way by simply including separate dummies for missing values. The main explanatory variable $C_{i}$ is equal to one if child $i$ enters childcare within two months of the official school entry period (August-September) in the year that she turns three and zero if entry occurs approximately twelve months later. The instrument $Z_{i}$ is the local supply of childcare places measured by the slot-child-ratio for children between age three and six and a half on the county level.

\footnotetext{
${ }^{12}$ These papers differ from ours in that they can exploit arguably random variation in childcare places within municipalities over time. Since we only observe one cohort, we cannot exploit temporal variation in the supply of childcare. However, an advantage of our data are the rich demographic and parental information that we can condition on.

${ }^{13}$ We describe the set of controls used in the analysis in more detail in Section 4.
} 
Our estimate for $\beta$ can be interpreted as the causal effect of early childcare entry under the assumption that conditional on our set of family characteristics, the local availability of childcare places is unrelated to pre-existing child outcomes or unobserved family background characteristics affecting student outcomes. Naturally, the local childcare supply is also affected by demand for childcare which in turn might be correlated with other unobserved factors that influence child outcomes. While the rich set of family background variables should alleviate concerns about remaining unobserved confounders, we additionally include several predictors of local childcare demand in $X_{i}$ from administrative data (German Federal Statistical Office, 2016; German Federal Office for Building and Regional Planning, 2018). These are measured at the county level and include income (per capita), the unemployment rate, the fraction of foreigners, the population density, the political vote share for conservative parties and the female employment share. In Section 5 we present evidence that, even after controlling for a set of demand factors, the first stage relationship remains strong. This supports the assumption that in our institutional setting regional differences in slot-childratios are to a large extent driven by differences in the supply of childcare places rather than the demand for them. We hypothesize that the rest of the unexplained variation in supply differences is likely to be random and can be attributed to decentralized budget planning and political bargaining at the county level. Still, any of these remaining differences across counties that are correlated with the supply of childcare places and adolescents' personality traits could lead to bias in the IV estimates. We provide some placebo tests to address these concerns in Section 7.

Under the assumption that our measure of supply $\left(Z_{i}\right)$ meets the exclusion restriction, i.e. it predicts early entry into childcare but correlates with students' personality traits only through its effect on early childcare entry, the IV estimates identify the local average treatment effect (LATE) (Angrist and Krueger, 1991). That is, we identify long run effects of an early childcare entry on personality traits for children who entered childcare approximately one year earlier because of larger supply of places in their county of residence. This is a highly relevant parameter for public policy, as it provides the treatment effect for those children who will enroll in childcare if the supply of universal childcare expands.

\section{Data}

For the empirical analyses we draw on four different data sets: (1) the German National Educational Panel Study (NEPS), administrative county level data ${ }^{14}$ on (2) 'slot-child-ratios'

\footnotetext{
${ }^{14}$ We use data from the years 1994 and 1998 (German Federal Statistical Office, 2016; German Federal Office for Building and Regional Planning, 2018).
} 
and (3) regional controls, and (4) the German Socio-Economic Panel Study (SOEP). ${ }^{15}$ The main analysis is based on the NEPS, a nationwide and representative multi-cohort panel study (see Blossfeld et al., 2011). The NEPS covers six age groups ranging from newborn children to adults. In total, it covers educational trajectories of more than 60,000 individuals. We focus on the starting cohort 4 (SC4), which is a sample of students who were first sampled in the school year 2010/2011 when they attended ninth grade. The full SC4 consists of approximately 15,000 students mainly born between 1994 and 1996. The data set contains comprehensive information regarding the students' skill development, learning environments, educational decisions and parental backgrounds. ${ }^{16}$ It furthermore provides retrospective information on childcare entry dates from which we infer the age in months at childcare entrance and classify children into treatment and control groups.

For the IV approach, we merge these data to administrative data on county-level slotchild-ratios defined as the ratio of available childcare places to the number of children in that age group. In our preferred specification we use the slot-child-ratio for children between age three and six for the year 1998. ${ }^{17}$ These data come from the statistics of children and youth welfare ('Kinder- und Jugendhilfestatistik') and were provided by the research data center (RDC) of the federal statistical office and the statistical offices of the federal states (Statistisches Bundesamt, 2013).

\subsection{Main sample restrictions}

We restrict our sample to students born between 1994 and 1996 who attend ninth grade in 2010 and for whom we have information on the exact starting date of childcare attendance. Further, we focus on students living in the former-West of Germany, since the former-East had already very high childcare attendance rates for three-year-old children (up to 98\%) in the mid-1990s (see again Figure 1 in Section 2). In addition, we discard all students without valid personality trait measures. These restrictions reduce the sample size from 15,000 to 6,813. ${ }^{18}$ Finally, to ensure that we measure the effect of entering childcare for students approximately twelve months apart, we focus on students who entered childcare within two months of the official school entry month (in August or September) in the year that they turn three or four. Our final sample consists of 4,579 students.

\footnotetext{
${ }^{15}$ We describe the SOEP data in Section 6.

${ }^{16}$ For more information on the SC4 see LIfBi (2016).

${ }^{17}$ In Section 7, we use the slot-child-ratio for the year 1994 as an alternative instrument for early childcare entry.

${ }^{18}$ The sample size is cut in half, because parents provided the information on students' childcare history and the response rates for parents in the NEPS are lower, because the sampling frame focuses on children in educational institutions.
} 
We match further information provided by their parents to this sample including migration background, single parenthood, household size, household income, maternal educational qualification level, maternal working status, and maternal age at childbirth. Summary statistics of all relevant characteristics are presented separately for students entering earlier (treatment group) and for those entering about one year later (control group), see Table 1.

\section{[Table 1 about here]}

The mean comparison of socio-demographic characteristics of adolescents in treatment and control groups shows that students in the treatment group are more likely to live in a single parent household, to have fathers with more years of schooling, and to live in higher income households (see Table 1). Table 1 further reveals that our instrumental variable, the regional slot-child-ratio, varies significantly between treatment and control groups. Thus, children in the treatment group reside, on average, in counties with a less restricted supply of childcare than children in the control group. This already points to the relevance of our instrument.

Furthermore, we also merge the following regional characteristics measured in 1998 at the county-level to our final sample and use them in our preferred specification as additional control variables: population density, per capita GDP, unemployment rate and the share of foreigners. These data are also provided by the German Federal Statistical Office (German Federal Statistical Office, 2016). Moreover, we use two additional regional covariates of interest from the INKAR database (German Federal Office for Building and Regional Planning, 2018). First, we use the female employment share at the county level in $1998{ }^{19}$ Second, we use data from official electoral vote share statistics for the election of the German Federal Parliament in 1998 provided by the INKAR database. From this, we construct an indicator of the county average share of valid party votes for either the Christian Democratic Union/Christian Social Union in Bavaria (CDU/CSU) or the Free Democratic Party (FDP). All three parties represent the more conservative German political spectrum. Therefore, a higher share of more conservative votes is used as an indicator for more conservative views on average per county. A smaller share of conservative votes represents higher shares of more liberal party votes for either the Social Democratic Party of Germany (SPD), the Left Party or the Green Party. This indicator allows us to include a measure of regional political attitudes and values as an additional covariate in our regressions.

\footnotetext{
${ }^{19}$ This measure captures only female employees in Germany who are subject to mandatory social insurance contributions, hence it does not include self-employed, or women working for the public sector. However, it covers roughly 70 percent of all women employed and is therefore most frequently used as measure for female labor supply.
} 


\subsection{Personality traits}

The NEPS SC4 data include measures of the Big Five personality traits which comprise the following five basic psychological dimensions: openness to experience, conscientiousness, extroversion, agreeableness, and neuroticism (see also McCrae and Costa, 1996, 1999). ${ }^{20}$ Compared to the original Big Five inventory, the personality traits in the NESP SC4 are measured with a validated short scale based on 10 items ("BFI-10") provided by Rammstedt and John (2007). ${ }^{21}$ Students in the SC4 self-rate their personality traits on a five-point scale (from 1 "disagree strongly" to 5 "agree strongly") for each item. For example, the dimension extroversion captures two items, for which students self-rate to which degree they regard themselves as outgoing or sociable and reserved. Table 2 shows the summary score of each personality trait dimension in the sample. For the analyses, we take the average over all relevant items for each trait and standardize each measure to have a mean of zero and a standard deviation of one. To account for gender differences in personality traits, we standardize separately by gender.

[Table 2 about here]

\section{Results}

We start by demonstrating the relevance of our instrument. Table 3 reports results for the first stage where we regress early childcare attendance at the age of three $\left(C_{i}\right)$ on the slot-child-ratio in $1998\left(Z_{i}\right)$ at the county-level. Columns 1 to 4 show that the slot-child-ratio is a strong predictor of starting childcare one year earlier; in all specification the F-Test is larger than 118. The size of the first stage coefficients changes only slightly when adding additional control variables. In our preferred specification in column 4 of Table 3, which includes proxy variables for the regional demand for childcare places (e.g. local population density, unemployment rate, etc.), the coefficient increases to 0.93 from 0.85 in column 1. This indicates almost a one-to-one relationship between the supply of early childcare and early entry; as the share of children for which a childcare slot is available increases by one percentage point, the probability of early entry into childcare also increases by one percentage point. This is exactly what we would expect in a setting with an under-provision of childcare slots where every additional slot is immediately filled.

[Table 3 about here]

\footnotetext{
${ }^{20}$ Table A.1 in the Appendix includes the definitions of all Big Five personality traits.

${ }^{21}$ See also Table A.2 in the Appendix for the questionnaire items used in NEPS to measure the Big Five.
} 
We next turn to the main results of the empirical model in Equation (1). The first four columns in Table 4 report OLS estimates of entering childcare one year earlier on the respective Big Five personality trait and step-wise adding more control variables. The first specification in column 1 only controls for birth month fixed effects while column 2 adds control variables for migration background, mother's age at childbirth, gender of the student, single parenthood, and mother's years of education. In column 3, we further include dummies for mothers' employment status, household income quartiles, and household size. The last specification shown in column 4 additionally includes regional characteristics. The estimates in column 1 suggest that children who enter childcare one year earlier are more likely to have higher levels of extroversion (around 0.11 SD) and openness (around 0.06 SD), and lower levels of conscientiousness (around -0.09 SD) at the age of fifteen. These estimates are robust to the inclusion of further control variables. ${ }^{22}$ The OLS results for conscientiousness and extroversion are statistically significantly different from zero at the one percent level across all specifications. Those on openness are significant at the five percent level and decrease in significance level to being marginally significant in column 3 and 4 .

Columns 5-8 report the result of the instrumental variable approach (IV) using the slotchild-ratio at the county level as instrument for early entrance in universal childcare. Again, we step-wise include further control variables. Effects are less precisely estimated in these specifications; standard errors increase five-fold compared to the OLS estimates. Hence, the IV results are less statistically significant albeit larger in size compared to the OLS results. Most importantly, the effect on extroversion remains positively significant and increases substantially in size to $0.37 \mathrm{SD}$. This effect is significant at the five percent level across all specifications and changes only slightly when including further control variables from 0.31 SD to 0.37 SD. This suggests that earlier childcare entry induced by a higher supply of childcare slots causally increases children's level of extroversion at age fifteen by 37 percent of a standard deviation. This is a substantial effect size. For example, it is larger than the effect of moving from the first to the third quartile of household income (0.215 SD, see Table A.6 in the Appendix). Moreover, the effect on conscientiousness switches sign compared to the OLS results. For children entering childcare earlier in the mid-1990s in counties with higher supply in places column 8 indicates an increase in conscientiousness of 0.25 SD by age fifteen. Albeit significant in size, the effect is not statistically significant at conventional levels (p-value 0.14). For the remaining three personality traits openness, agreeableness, and

\footnotetext{
${ }^{22}$ For the sake of brevity, we only show the coefficient of main interest, early childcare entry, even though some additional variables are statistically significantly correlated with personality traits. See Table A.6 for the full results. For example, household income is significantly and positively correlated with extroversion. Furthermore, children of employed mothers are also more likely to have a higher level of extroversion.
} 
neuroticism, we cannot conclude that entering childcare earlier has a statistically significant impact on them.

[Table 4 about here]

The results in Table 4 raise the question of what explains the differences between the OLS and IV estimates for conscientiousness and extroversion. One explanation for these difference could be effect heterogeneity. Our IV estimates only capture the LATE of entering childcare approximately one year earlier for children who enter earlier because of a larger supply of childcare places in their respective county. The effect for these complier children might differ from the average treatment effect. To test whether complier children differ from the rest of our sample, we characterize the complier population in terms of several background characteristics in Table 5 . In this analysis $Z$ is defined as a binary variable equal to zero if the slot-child-ratio is below the $33^{\text {rd }}$ slot-child-ratio percentile and equal to one if it is above the $66^{\text {th }}$ percentile. $C_{1 i}$ indicates early childcare entry when $Z=1$ and $C_{0 i}$ when $Z=1$. The ratios in column 3 of Table 5 give the relative likelihood of compliers having characteristics shown in the utmost left column of this table. We see that complier children are more likely to be from disadvantaged backgrounds; they are more likely to live in single parent households and have mothers without post-secondary education. Cornelissen et al. (2018) provide evidence that children from disadvantaged backgrounds benefit more from childcare because of worse outcomes when not enrolled in childcare. This heterogeneity could explain why our IV estimates are considerably larger than the corresponding OLS results.

\section{[Table 5 about here]}

\section{Further analysis}

To check whether our previous findings are the results of multiple testing, we replicate the main analyses in Table 4 with data from the German Socio-Economic Panel Study (SOEP). In addition to cross validating our results, the SOEP allows to further assess the validity of our IV approach because it contains additional information, in particular Big Five measures for parents. These are potentially important controls because childcare choices are in part

explained by parental personality traits (for example, see Bjerre et al., 2011) and personality traits have been shown to be transmitted from parents to children (Anger, 2011). Hence, controlling for parental personality traits should be informative about potential omitted variable bias.

The SOEP has been carried out since 1984 and is an annual nationwide random German household panel survey with more than 30,000 individuals in approximately 17,000 households 
participating in 2017 (see Wagner et al., 2007). Similar to the NEPS data the longitudinal design allows to examine long run effects of attending universal childcare earlier on personality traits. Although the SOEP has advantages due to its household sampling approach compared to the NEPS, we are left with a rather small sample after imposing the same sample restrictions as in our main sample (see Section 4). The final SOEP sample comprises 631 seventeen-year-olds from initially 3,525 adolescents ${ }^{23}$ and covers a wider range of birth cohorts, i.e. children born between 1990 and 1998. ${ }^{24}$ For 631 adolescents we have information on personality traits, childcare attendance at age three, month of birth, county of residence, parental personality traits, as well as maternal, household and regional characteristics from the years when the adolescents turned three. Similar to the NEPS Big Five inventory, personality traits in the SOEP are also measured using a modified version (Dehne and Schupp, 2007) of the Five Factor Model by McCrae and Costa (1996, 1999). In the SOEP, adolescents self-rate their personality traits based on a set of 16 statements (see Table A.2 in the Appendix for an overview). All questions are answered on a seven-point Likert type scale (from 1 "does not apply to me at all" to 7 "applies to me perfectly"). Again, we sum the relevant items determining each dimension of the five personality traits with scores ranging from 1 to 7 , and standardize these measures by gender, to have zero mean and a standard deviation of one (see also Table 1 in the Appendix).

[Table 6 about here]

Table 6 shows OLS and IV estimates for the SOEP data controlling for an even larger set of characteristics which are likely to be correlated with both early childcare entry and adolescents' personality traits. Since the personality traits of parents and their children are modestly correlated, ${ }^{25}$ we would expect OLS coefficients to change once we additionally control for parents' personality traits if there is selection into early childcare based on children's personality. However, comparing OLS results with and without controlling for parent's personality traits in columns 1 and 2 of Table 6 yields very similar results for all five personality traits. This speaks against selection bias as an explanation for the observed OLS estimates. Importantly, the results for extroversion can be replicated with the SOEP data: The OLS results for extroversion in columns 1-3 are significantly positive and somewhat

\footnotetext{
${ }^{23}$ The surveying of personality traits was only introduced in 2006 in the youth questionnaire. Restricting the sample to observations with Big Five measures and valid information on childcare attendance leads to a large drop in sample size, as nearly 40 percent of adolescents stem from a large refreshment sample in 2000. For those students we do not have any information on childcare attendance in the mid-1990s.

${ }^{24}$ See Table A.5 in the Appendix for descriptive statistics of this sample.

${ }^{25}$ Anger (2011) reports correlations in Big Five measures between parents and their adolescent children ranging from 0.12 to 0.24 for the SOEP data.
} 
larger than the NEPS results. The estimate for the specification with the full set of control variables suggests that entering childcare one year earlier is associated with a 0.21 SD increase in extroversion. Although the associated standard errors and confidence intervals are quite large, the IV estimates also clearly indicate a significant positive effect of early childcare on extroversion of about $0.59 \mathrm{SD} .{ }^{26}$ For the OLS specifications, we further find significant positive effects for openness and negative effects for neuroticism. The magnitude of these effects are similar in the IV specifications, but because of the increase in standard errors, they lose statistical significance. Importantly, controlling for personality traits in the IV specification also does not affect the estimates. This alleviates concerns that any potential relationship between parental personality traits and the supply of childcare biases our IV results.

\section{Sensitivity analysis}

In this section, we further test the robustness of our results. One concern is that our instrument, the slot-child-ratio, partly captures unmeasured parental preferences for early childcare even after conditioning on an extensive set of background variables. This is a threat to our identification strategy if these preferences are also related to child outcomes. As a robustness check we, therefore, use the slot-child-ratio at the county-level in 1994 instead of 1998 as an instrument for early childcare entry. This is a measure of supply from the year prior to the birth of the students in the NEPS sample, who were mostly born in 1995 and 1996. If parental preferences are not perfectly correlated over time, the earlier supply should capture less of the parental preferences for childcare for the children in our sample, but already reflect regional differences in the supply of childcare. Table 7 shows that results using the 1994 ratio as an instrument are very similar to the main results in Table 4 . The estimated effect for extroversion is $0.33 \mathrm{SD}$ in our preferred specification and the estimates for conscientiousness are positive, albeit statistically insignificant at conventional significance levels. ${ }^{27}$ There is also a large and significant effect on agreeableness, which, however, vanishes once regional controls are included.

\section{[Table 7 about here]}

Another threat to identification would be selective migration of parents into areas with a larger supply of childcare places. However, regional mobility patterns across counties

\footnotetext{
${ }^{26}$ The first stage in the SOEP sample is less strong compared to the NEPS, but the F-statistics is still larger than 10 (see Table A.4 in the Appendix).

${ }^{27}$ The p-value of the coefficient in column 3 of Table 7 equals 0.18 .
} 
for the year 1996 reveal no systematic pattern between migration and childcare availability (see Figure A.1 in the Appendix). Felfe and Lalive (2012) provide additional evidence that mobility of parents in Germany is very low and unrelated to the number of childcare slots per county. We further test the validity of the instrument by falsification tests where we estimate the effect of an additional year of childcare on arguably pre-determined outcomes of children. Table 8 reports the results for these placebo regressions for height, an indicator for low birth weight, and premature birth, using the same specifications as in Table 4. Unfortunately, the latter two outcomes are only available for roughly half of the sample. If our previous results are capturing a causal impact of earlier entry into childcare, then we should not observe any significant effects in these regressions. This is indeed what we find. None of these outcomes are statistically significantly affected by early childcare entry.

\section{[Table 8 about here]}

The SOEP results with additional controls for parental Big Five traits alleviate concerns that our findings can be explained by regional differences in personality traits that correlate with the local supply of childcare places. Yet, to provide further evidence that our effects for extroversion are not driven by this, we also investigate regional differences in extroversion. To this end, we aggregate information on adults' personality traits in 2005 at the countylevel from the SOEP. We use information for all adults in the SOEP rather than the sample restricted to parents used for our results in Table 6. This increases the sample to roughly 20,000 adult observations. 2005 is the first year that the Big Five personality traits were surveyed. The measures from 2005 should be good proxies for the regional distribution of extroversion among adults in 1998, because mobility is low in Germany and the Big Five have been shown to be relatively stable in adulthood (e.g. McCrae and Costa, 1996; CobbClark and Schurer, 2012). Figure 4 (b) shows a map of these aggregated extroversion levels. There is no clear discernible pattern and regional differences in extroversion appear to be unrelated to the supply of childcare places shown in Panel (a). We also use these aggregated personality measures as additional regional controls in our baseline IV specifications. This produces very similar results to those in Table 6 reported above. As an additional robustness check, we drop counties from the federal state of Baden-Wuerttemberg from the analyses, since they have the highest supply of slots (see Figure 2 (a)). This gives very similar results, but standard errors increase substantially.

[Figure 4 about here]

To further check whether differences in parental preferences across counties could drive our results, we plot in Figure 4 (c) conservative vote shares in the 1998 election of the 
German Federal Parliament as a proxy for regional political attitudes. The map shows clear patterns for regional differences in political attitudes. For example, the south-east of Germany is clearly more conservative with conservative vote shares between $46 \%$ and $66 \%$ compared to the north-west of Germany, where the conservative vote share ranges from $25 \%$ to $46 \%$. Looking at Figure 4 (c), it shows that the conservative vote share and the availability of childcare places are negatively correlated, which is not surprising given that more liberal governments are more likely to invest in childcare places to increase maternal employment. ${ }^{28}$ In the same vein, Figure 4 (d) shows that the higher supply of childcare in the south-west of Germany also corresponds to higher female employment. It is not clear how these regional differences in political attitudes and female employment affect our estimates. Therefore, all specification with regional controls include the conservative vote share and female employment rates as proxies for the demand for childcare.

Overall, the sensitivity analyses confirm the main findings presented in Section 5. For students who attend childcare starting from age three onward we find a large increase in extroversion at age fifteen compared to students who started approximately one year later. This suggests that one additional year of universal childcare fosters more communicative and conscientious students when there is less restrictive access to childcare.

\section{Discussion and Conclusion}

This paper analyzes the long-run effect of early entry in universal childcare at age three compared to age four on non-cognitive skills in adolescence. Specifically, we look at the effect of one additional year of childcare on the Big Five personality traits in adolescence when children are fifteen years old. We use German data from the NEPS and exploit geographical disparities in the local supply of childcare places in an instrumental variable approach. Both OLS and IV estimates suggest that starting childcare earlier at age three versus age four significantly increases students' levels of extroversion in adolescence and to some extent conscientiousness. We can replicate these results in a smaller data set based on another nationwide representative sample from the SOEP.

Our findings show that students' personality traits are affected by an additional year of universal childcare. This indicates that childcare impacts on non-cognitive skills beyond short-run outcomes. Our instrument, the slot-child-ratio in 1998 at the county level as an indicator for sufficient supply of childcare places, is a strong and relevant predictor of early childcare entry in the western federal states in Germany. We find a large and robust positive effect for the personality trait extroversion, i.e. for students' level of 'sociableness'

\footnotetext{
${ }^{28}$ These results are available upon request from the authors.
} 
and 'tendency to enjoy to interact in their surroundings'. This finding supplements previous findings on medium- or long-run effects of universal childcare attendance also accounting for unobserved heterogeneity in childcare participation (Apps et al., 2013; Goodman and Sianesi, 2005; Baker et al., 2019; Müller et al., 2013).

Baker et al. (2019) provide compelling evidence from a quasi-experiment of introducing universal childcare in one province in Canada (Quebec) in favor of childcare effects working through the non-cognitive channel. While they do not identify any effects on cognitive skills using two large national data sets on test score performance, they find negative effects on non-cognitive child outcomes, namely, a significant worsening in self-reported health and life satisfaction among teens as well as a sharp increase in criminal behavior among the treated cohorts. Despite the opposite sign of affected outcomes, their results strengthen the central role of childcare affecting non-cognitive skills in the long-run in line with our study. As discussed in Currie and Almond (2011) the negative effects can likely be attributed to the particular setting of the program introduction leading to deterioration in childcare quality.

Our results are also in line with Müller et al. (2013) who examine SOEP data from 1984-2010. They find that more years spent in universal childcare lead to higher levels of extroversion compared to peers with shorter years of childcare using OLS (0.07 SD) and a Heckman correction approach (0.03 SD). Hence, an additional year spent in childcare is associated with an increase of seven percent of a standard deviation. This is lower than our estimate in the SOEP sample (0.21 SD), which likely differs due to methodological differences.

In contrast to our study, Apps et al. (2013) do not find any evidence of better well-being, petty crime involvement or improved health induced by pre-school attendance in their UK study. We argue that these differences most likely stem from our more refined definition of childcare attendance comparing children entering childcare one year earlier than their peers in contrast to examining attending versus not-attending. In addition, our outcome variables might represent dimensions of the non-cognitive skill set that are more responsive to earlier exposure to childcare.

Interestingly, Kuehnle and Oberfichtner (2017) do not find any effect of early childcare attendance on non-cognitive skills also using NEPS data with a fuzzy-regression discontinuity design. They exploit the fact that in regions with sufficiently many childcare slots, childcare centers often gave priority to children who had not turned three yet (hence who were not eligible to a free slot according to the legal claim) but who would turn three within the calendar year. Therefore, Kuehnle and Oberfichtner (2017) estimate an effect of childcare on cognitive and non-cognitive skills by comparing children who enter even earlier than mandated to children who enter on time at age three. They hypothesize that they capture effects for children of parents with strong preferences for early childcare who are unlikely to 
gain much from an earlier childcare entry. We believe that our findings differ because the group of complier children for our instrument is likely to be different. Our approach mostly compares children who enter childcare on time (in the year they turn three) with children who enter one year later due to a shortage of places. Hence, compliers in our setting are likely to be children of parents with a weaker preference for public childcare compared to Kuehnle and Oberfichtner (2017)'s group of compliers. Cornelissen et al. (2018) have shown that children from families with a weaker preference for public childcare are more likely to benefit from it because of their worse outcomes when not enrolled. Judging from the institutional landscape at that time of severe rationing of childcare places, we also believe that our effects should be more representative for the population at large.

Our findings are also related to the economic literature using non-cognitive skills as input factors in estimations of even longer run outcomes, such as educational attainment and wages (for an overview, see Almlund et al., 2011). In particular, we show that personality traits in adolescence can be affected by early childhood experiences and environments. Studies in the psychological literature suggest that having a high score on extroversion helps individuals to react to negative life events, as they might be more able to rely on personal resources (for example, see findings of Sarubin et al., 2015). Fletcher (2013) provides evidence using sibling differences of young adults from the U.S. on the importance of personality measures for labor market success. In particular, he finds that extroversion leads to favorable labor market outcomes. A one standard deviation increase in extroversion increases employment by two percentage points and earnings by five to six percentage points which is robust over all specifications. When making the strong assumption of similar labor market norms in the U.S. and Germany, a rough back of the envelope calculation suggests that our results could translate into an increase of employment by 0.74 percentage points and an 1.85 percent increase in earnings (approximately $740 \$$ a year) for the compliers who attend one additional year of universal childcare. Future research might help to nourish this empirical question and to identify direct effects of childcare entry on labor market performance also within the European context.

Evaluating the implications of our study, we argue that our results are of particular interest to policy makers, as we find positive effects for children, who were shifted into early childcare through less restricted availability. For these complier children we observe a significant positive non-cognitive skill development, which supports to continue the rollout of the childcare system removing remaining entrance barriers. Today, the public focus has shifted to children starting childcare even earlier below the age of three. Even though conclusions from our study cannot directly be transferred to younger age groups, we hypothesize that the underlying mechanisms assigning children into early or late entry 
persist until today. Parents and their younger children still face the same rationing as well as geographical variation in the provision of childcare discussed in this paper. Whether or not children's non-cognitive skill development is also affected by an early entry at age one remains an important question for future research. This paper, however, provides a strong case for including non-cognitive development as a core determinant when evaluating the long-term success of universal childcare programs. 


\section{References}

Almlund, M., A. L. Duckworth, J. Heckman, and T. Kautz (2011). Personality Psychology and Economics. In E. A. Hanushek, S. Machin, and L. Wössmann (Eds.), Handbook of the Economics of Education, 4, Chapter 1, pp. 1-181. North Holland, Amsterdam: Elsevier.

Alt, C., B. Gedon, S. Hubert, K. Hüsken, and K. Lippert (2018). DJI-Kinderbetreuungsreport 2018 - Inanspruchnahme und Bedarfe bei Kindern bis 14 Jahren aus Elternperspektive ein Bundesländervergleich. DJI 2018, Deutsches Jugendinstitut, München.

Anger, S. (2011, May). The Intergenerational Transmission of Cognitive and Non-Cognitive Skills During Adolescence and Young Adulthood. IZA Discussion Papers 5749, Institute of Labor Economics (IZA).

Angrist, J. D. and A. B. Krueger (1991). Does compulsory school attendance affect schooling and earnings? Quarterly Journal of Economics 106(4), 979-1014.

Apps, P., S. Mendolia, and I. Walker (2013). The impact of pre-school on adolescents' outcomes: Evidence from a recent english cohort. Economics of Education Review 37, 183-199.

Baker, M., J. Gruber, and K. Milligan (2008). Universal child care, maternal labour supply, and family well-being. Journal of Political Economy 116(4), 709-745.

Baker, M., J. Gruber, and K. Milligan (2019). The long-run impacts of a universal child care program. American Economic Journal: Economic Policy (forthcoming).

Baron, J. D. and D. Cobb-Clark (2010). Are young people's educational outcomes linked to their sense of control? IZA Discussion Paper No. 4907, IZA, Bonn.

Bauernschuster, S. and M. Schlotter (2015). Public child care and mothers' labor supply evidence from two quasi-experiments. Journal of Public Economics 123(C), 1-16.

Berlinski, S., S. Galiani, and P. Gertler (2009). The effect of pre-primary education on primary school performance. Journal of Public Economics 93(1), 219-234.

Bietenbeck, J. (2019). The long-term impacts of low-achieving childhood peers: Evidence from project star. Journal of the European Economic Association (online first 7 January 2019), 1-35.

Bjerre, L., F. H. Peter, and C. K. Spiess (2011). Child Care Choices in Western Germany Also Correlated with Mothers' Personality. DIW Economic Bulletin 5, 20-26. 
Blanden, J., P. Gregg, and L. Macmillian (2007). Accounting for intergenerational income persistence: non-cognitive skills, ability and education. Economic Journal 117(519), C43C60.

Blossfeld, H.-P., J. von Maurice, and T. Schneider (2011). The National Educational Panel Study: need, main features and research potential. Zeitrschrift für Erziehungswissenschaft 14, 5-17.

Borghans, L., A. L. Duckworth, J. Heckman, and B. ter Weel (2008). The economics and psychology of personaltiy traits. Journal of Human Resources 43, 972-1059.

Brilli, Y., D. Del Boca, and C. Pronzato (2011). Exploring the impacts of public childcare on mothers and children in italy: Does rationing play a role? IZA Discussion Paper No. 5918, IZA, Bonn.

Brunello, G. and M. Schlotter (2011). Non cognitive skills and personality traits: Labour market relevance and their development in education \& training systems. IZA Discussion Paper No. 5743, IZA, Bonn.

Büchel, F., J. R. Frick, and C. K. Spiess (2002). Kinderbetreuung in West- und Ostdeutschland: Soziökonomischer Hintergrund entscheidend. DIW-Wochenbericht 31, $518-524$.

Büchner, C. and C. K. Spiess (2007). Die Dauer vorschulischer Betreuungs- und Bildungserfahrungen: Ergebnisse auf der Basis von Paneldaten. DIW Discussion Paper No. 687, DIW, Berlin.

Caliendo, M., D. Cobb-Clark, and A. Uhlendorff (2015). Locus of control and job search strategies. Review of Economics and Statistics 97(1), 88-103.

Camehl, G. F. (2016). Wie beeinflusst der Besuch einer Kindertageseinrichtung nichtkognitive Fähigkeiten? DIW Roundup No.105, DIW Berlin.

Chetty, R., J. N. Friedman, N. Hilger, E. Saez, D. W. Schanzenbach, and D. Yagan (2011). How does your kindergarten classroom affect your earnings? Evidence from project star *. The Quarterly Journal of Economics 126(4), 1593-1660.

Cobb-Clark, D. A. and S. Schurer (2012). The stability of big-five personality traits. Economics Letters 115(1), 11-15. 
Cornelissen, T., C. Dustmann, A. Raute, and U. Schönberg (2018). Who benefits from universal child care? Estimating marginal returns to early child care attendance. Journal of Political Economy 126(6), 2356-2409.

Cunha, F. and J. J. Heckman (2007). The techonology of skill formation. American Economic Review Papers and Proceedings 97(2), 31-47.

Cunha, F. and J. J. Heckman (2008). Formulating, identifying and estimating the technology of cognitive and non-cognitive skill formation. Journal of Human Resources 43(4), 738782.

Currie, J. and D. Almond (2011). Human capital development before age five. In Handbook of labor economics, Volume 4, pp. 1315-1486. Elsevier.

Datta Gupta, N. and M. Simonsen (2010). Non-cognitive child outcomes and universal high quality child care. Journal of Public Economics 94 (1-2), 30-43.

Datta Gupta, N. and M. Simonsen (2012). The effects of type of non-parental child care on pre-teen skills and risky behavior. Economics Letters 116(3), 622-625.

DeCicca, P. and J. Smith (2013). The long-run impacts of early childhood education: Evidence from a failed policy experiment. Economics of Education Review 36, 41-59.

Dehne, M. and J. Schupp (2007). Persönlichkeitsmerkmale im Sozio-oekonomischen Panel (SOEP): Konzept, Umsetzung und empirische Eigenschaften. Research Notes 26, DIW Berlin.

Deutscher Bildungsrat (1970). Empfehlungen der Bildungskommission. Strukturplan für das Bildungwesen. Stuttgart: Klett.

Drange, N., T. Havnes, and A. M. Sandsør (2016). Kindergarten for all: Long run effects of a universal intervention. Economics of Education Review 53, 164-181.

Dumas, C. and A. Lefranc (2010). Early schooling and later outcomes: Evidence from pre-school extension in france. THEMA Working Paper No. 2010-07, Université de CergyPontoise.

Felfe, C. and R. Lalive (2012). Early child care and child development: For whom it works and why. IZA Discussion Paper No. 7100, IZA Bonn.

Felfe, C. and R. Lalive (2018). Does early child care affect children's development? Journal of Public Economics 159, 33-53. 
Fessler, P. and A. Schneebaum (2016). The returns to preschool attendance. Department of Economics Working Paper No. 233, Vienna University of Economics and Business.

Fletcher, J. M. (2013). The effects of personality traits on adult labor market outcomes: Evidence from siblings. Journal of Economic Behavior and Organization 89, 122-135.

German Federal Institute for Population Research (2018). Regional net mobility (Binnenwanderungen) in 1996 in Germany. https://www.bib.bund.de/DE/Fakten/ Migration/Binnenwanderung.html.

German Federal Office for Building and Regional Planning (2018). INKAR database: 'Indikatoren und Karten zur Raum- und Stadtentwicklung (INKAR). Ausgabe 2018. Hrsg.: Bundesinstitut für Bau-, Stadt- und Raumforschung (BBSR) im Bundesamt für Bauwesen und Raumordnung (BBR) - Bonn 2018'. https://www.inkar.de/.

German Federal Statistical Office (2016). GENESIS-Online Datenbank. https:// wwW-genesis.destatis.de/genesis/online.

Goodman, A. and B. Sianesi (2005). Early education and children's outcomes: How long do the impacts last? Fiscal Studies 26(4), 513-548.

Havnes, T. and M. Mogstad (2011). No child left behind: Subsidized child care and children's long-run outcomes. American Economic Journal: Economic Policy 3(May 2011), 97-129.

Heckman, J., R. Pinto, and P. Savelyev (2013). Understanding the mechanisms through which an influential early childhood program boosted adult outcomes. American Economic Review 103(6), 2052-2086.

Heckman, J., J. Stixrud, and S. Urzua (2006). The effects of cognitive and noncognitive abilities on labor market outcomes and social behavior. Journal of Labor Economics 24(3), 411-482.

Heineck, G. and S. Anger (2010). The returns to cognitive abilities and personality traits in germany. Labour Economics 17(3), 535-546.

Jessen, J., S. Schmitz, C. K. Spiess, and S. Waights (2018). Kita- Besuch hängt trotz ausgeweitetem Rechtsanspruch noch immer vom Familienhintergrund ab. DIW Wochenbericht 38, 803-813.

Juhn, C. and K. M. Murphy (1997). Wage inequality and family labor supply. Journal of Labor Economics 15(1), 72-97. 
Kautz, T., J. J. Heckman, R. Diris, B. ter Weel, and L. Borghans (2014). Fostering and measuring skills: Improving cognitive and non-cognitive skills to promote lifetime success. NBER Working Paper 20749, Cambridge Massachusetts.

Kreyenfeld, M. and K. Hank (2000). Does the availability of child care influence the employment of mothers? Findings from Western Germany. Population Research and Policy Review $19(4), 317-337$.

Kreyenfeld, M., C. K. Spiess, and G. G. Wagner (2001). Finanzierungs- und Organisationsmodelle institutioneller Kinderbetreuung. Analysen zum Status quo und Vorschläge zur Reform. Neuwied: Hermann Luchterhand Verlag.

Kuehnle, D. and M. Oberfichtner (2017). Does early child care attendance influence children's cognitive and non-cognitive skill development? IZA Discussion Paper No. 10661, IZA, Bonn.

LIfBi (2016). Starting Cohort 4: Grade 9 (SC4) - Study Overview Waves 1 to 8. Research Data, National Educational Panel Study, Leibniz Institute for Educational Trajectories (LIfBi).

Loeb, S., M. Bridges, D. Bassok, B. Fuller, and R. W. Rumberger (2007). How much is too much? The influence of preschool centers on children's social and cognitive development. Economics of Education Review 26(1), 52-66.

Lundberg, S. (2013). The college type: Personality and educational inequality. Journal of Labor Economics $31(3)$, pp. 421-441.

Magnuson, K. A., C. Ruhm, and J. Waldfogel (2007). Does prekindergarten improve school preparation and performance? Economics of Education Review 26 (1), 33-51.

McCrae, R. and P. J. Costa (1996). Toward a new generation of personality theories: Theoretical contexts for the five-factor model. In J. Wiggins (Ed.), The Five Factor Model of Personality: Theoretical Perspectives, pp. 51-87. New York: Guilford.

McCrae, R. and P. J. Costa (1999). A five-factor theory of personality. In L. A. Pervin and O. John (Eds.), Handbook of Personality: Theory and Research, pp. 139-153. New York: Guilford.

Mueller, G. and E. Plug (2006). Estimating the effect of personality on male-female earnings. Industrial and Labor Relations Review 60(3), 3-22. 
Müller, K. U., C. K. Spiess, C. Tsiasioti, K. Wrohlich, et al. (2013). Evaluationsmodul: Förderung und Wohlergehen von Kindern. Politikberatung kompakt Nr. 73, DIW Berlin.

Peter, F., P. S. Schober, and C. K. Spiess (2016). Early birds in day care: The social gradient in starting day care and children's non-cognitive skills. CESifo Economic Studies 62(4), $725-751$.

Prevoo, T. and B. ter Weel (2015). The importance of early conscientiousness for socio-economic outcomes: Evidence from the British Cohort Study. Oxford Economics Papers 67(4), 918-948.

Rammstedt, B. and O. P. John (2007). Measuring personality in one minute or less: A 10-item short version of the big five inventory in english and german. Journal of Research in Personality 41, 203-212.

Sarubin, N., M. Wolf, I. Giegling, S. Hilbert, F. Naumann, D. Gutt, A. Jobst, L. Sabaß, P. Falkai, D. Rujescu, M. Bühner, and F. Padberg (2015). Neuroticism and extraversion as mediators between positive/negative life events and resilience. Personality and Individual Differences 82, 193-198.

Schober, P. S. and C. K. Spiess (2013). Early childhood education activities and care arrangements of disadvantaged children in Germany. Child Indicators Research 6, 709735.

Schultz, T. P. (1990). Testing the neoclassical model of family labor supply and fertility. Journal of Human Resources 25(4), 599-634.

Spiess, C. K. (1998). Staatliche Eingriffe in Märkte für Kinderbetreuung. Analysen im deutsch-amerikanischen Verleich (37 ed.). Frankfurt a.M and New York: Campus Verlag.

Spiess, C. K. (2008). Early childhood education and care in Germany: The status quo and reform proposals. Zeitschrift für Betriebswirtschaftslehre 2008 67, 1-20.

Spiess, C. K. and C. Büchner (2009). Children who attend formal day care do better in school - even many years later in secondary school. DIW Weekly Report 5, 31-34.

Statistisches Bundesamt (2013). Kinder- und Jugendhilfestatistik: Betreuungsquoten der Kinder unter 6 Jahren in Kindertagesbetreuung am 01.03.2013. https://www destatis . $\mathrm{de} / \mathrm{de} /$ themen/gesellschaft-umwelt/soziales/kindertagesbetreuung/_inhalt. html, German Federal Statistical Office, Wiesbaden. 
Wagner, G. G., J. R. Frick, and J. Schupp (2007). The German Socio-Economic Panel Study (SOEP) - Scope, evolution, and enhancements. Schmollers Jahrbuch 127(1), 139-169.

Wrohlich, K. (2008). The excess demand for subsidized child care in Germany. Applied Economics 40(10), 1217-1228. 


\section{Tables and figures}

Figure 1: Childcare attendance rates in Germany (1991-2003)
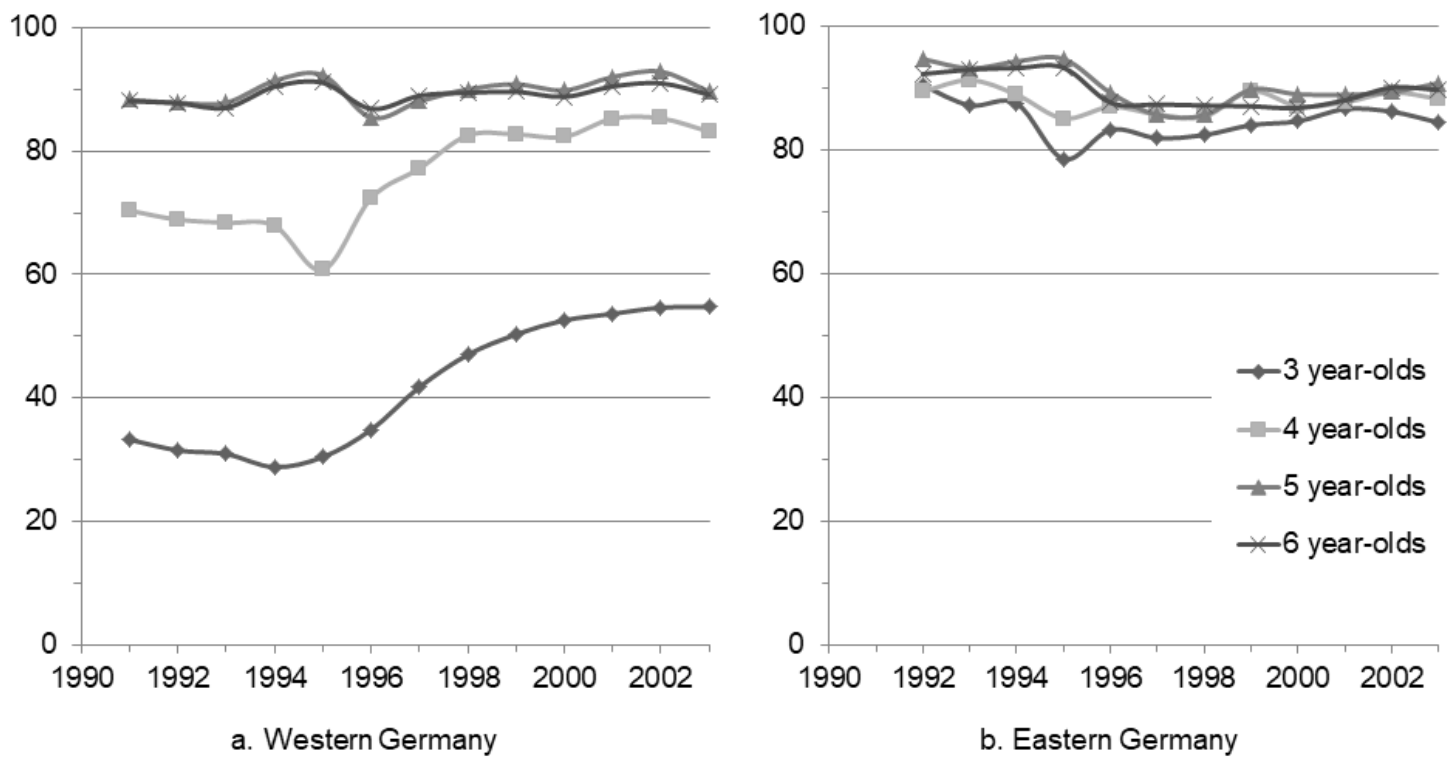

Notes: The left side shows the percentage share of children of the respective age group who attend childcare in the western German federal states (including former-West Berlin), while the right side displays childcare attendance rates in the former-Eastern German federal states (including former-East Berlin) between 1991 and 2003. Source: Statistical Offices, Bevölkerungsfortschreibung, Fachserie 1, Reihe 1.3, Microcensus, Calculations of the Dortmunder Arbeitsstelle Kinder- und Jugendhilfestatistik, own graphical display. 
Figure 2: Coverage map for childcare provision in western Germany (slot-child-ratio at county level)

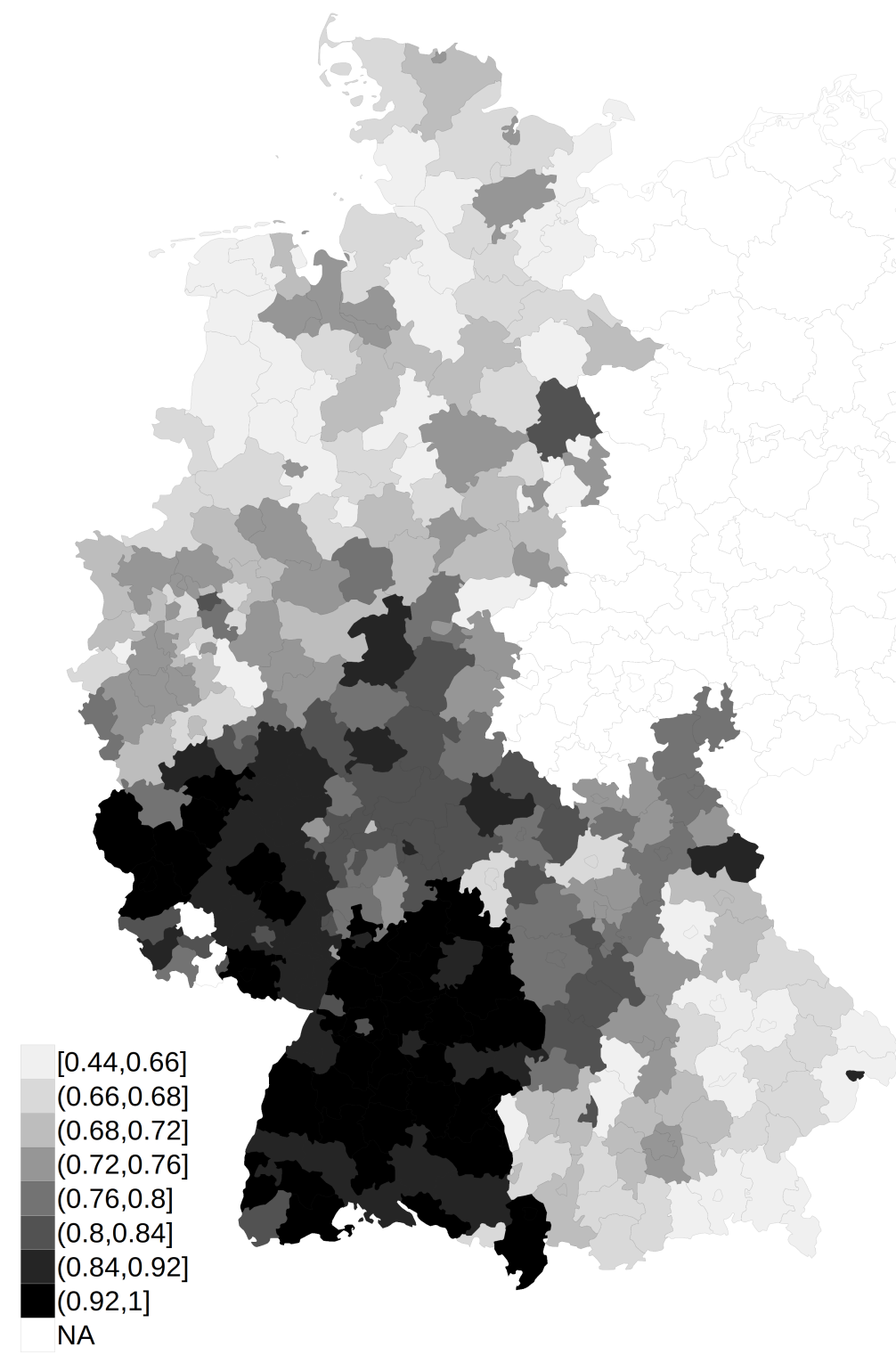

Notes: This figure shows the slot-child-ratio for children between age three and six and a half aggregated at the county level in western Germany measured in the year 1998. The map reveals a very heterogeneous level of childcare provision. In the institutional context of severe rationing, slots are all filled. Hence, the slot-child-ratio measures the supply as well as the regional attendance of childcare. In some counties, only 44 percent of children in the relevant three to six and a half years old age group attend childcare (light grey areas), while a few counties have a high level of childcare provision with more than 92 percent of children enrolled in childcare (black areas). Source: RDC of the Federal Statistical Office and the Statistical Offices of the Länder on the county level, statistics of children and youth welfare (Kinder- und Jugendhilfestatistik) for 1998, own graphical display. 
Figure 3: Childcare entry regimes of adolescents (NEPS)

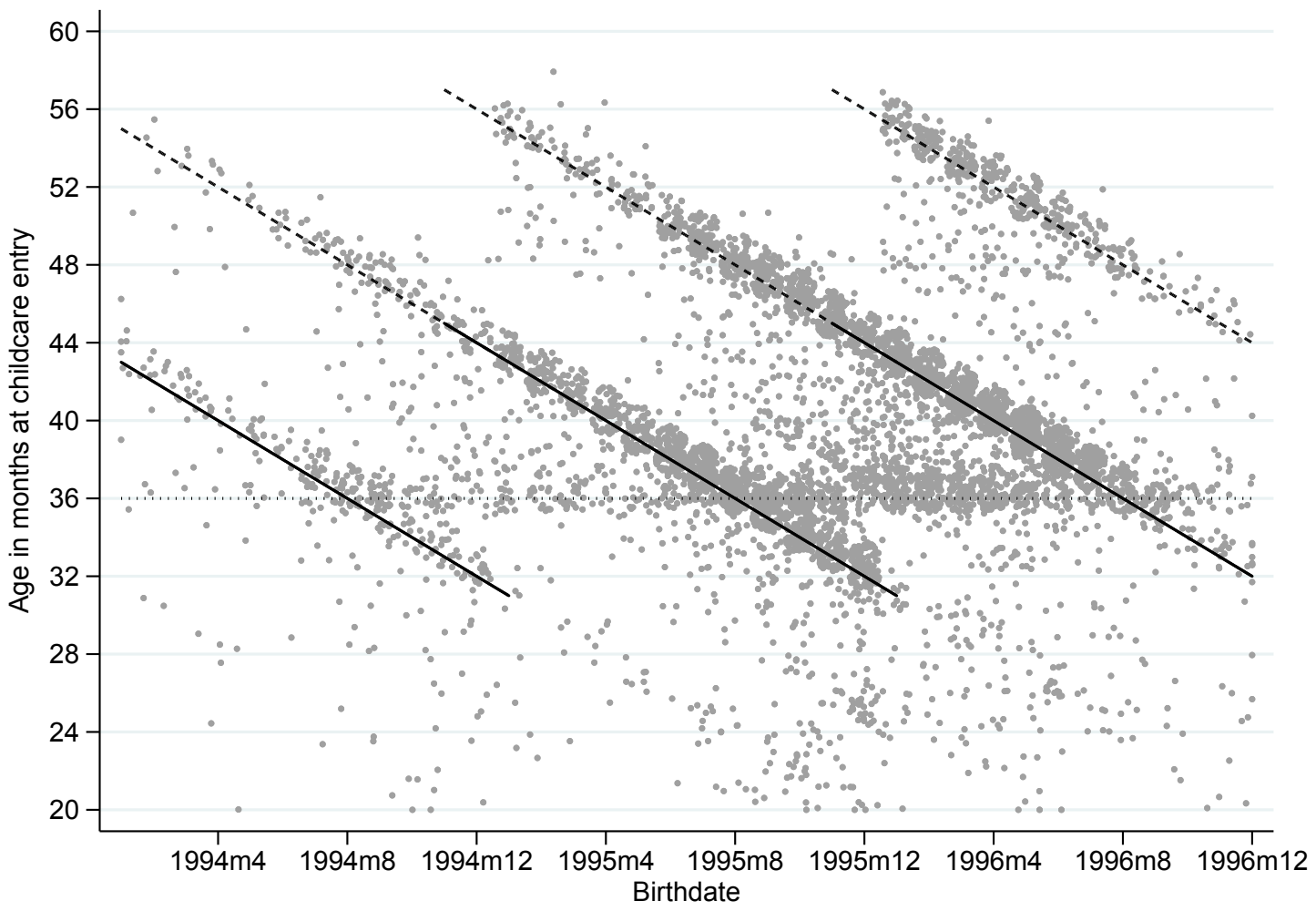

Notes: This figure shows childcare entry for adolescents in the NEPS SC4 born between 1994 and 1996. On the vertical axis, children's age in month at childcare entry is depicted and on the horizontal axis their month of birth. Data points close to the solid line correspond to children who enter childcare in compliance with the legal claim of 1996 (in the year they turn three), while the data points close to the dashed line represent children who have to wait approximately one additional year before entering childcare due to a shortage of available childcare slots. Thus, these children are more likely to enter childcare at age four. Source: NEPS Data, Data Version SC4: 7.0.0 remote access, own calculations and graphical display. 
Table 1: Summary statistics of relevant characteristics by treatment status (NEPS)

\begin{tabular}{lccc}
\hline & \multicolumn{2}{c}{ Mean } & \multirow{2}{*}{ Mean differences } \\
\cline { 2 - 3 } & Control group & Treatment group & \\
\hline \hline Child characteristics: & & & \\
Age at childcare entry in months & 48.87 & 38.20 & $10.67^{* * *}$ \\
Age at school entry in years & 6.63 & 6.53 & $0.10^{* * *}$ \\
Age at interview in years & 15.16 & 15.06 & $0.10^{* * *}$ \\
Migration Background & 0.23 & 0.26 & $-0.03^{*}$ \\
Male & 0.54 & 0.51 & 0.02 \\
Parental characteristics: & & & \\
Mother working & 0.80 & 0.82 & -0.02 \\
Single parent & 0.07 & 0.09 & $-0.02^{*}$ \\
Mother's years of education & 13.35 & 13.46 & -0.11 \\
Father's years of education & 13.74 & 13.92 & $-0.18^{*}$ \\
Mother's age at birth & 29.62 & 29.75 & -0.13 \\
Household characteristics: & & & \\
Household Income & & & -0.01 \\
$\quad$ First quartile & 0.18 & 0.19 & $0.04^{* *}$ \\
$\quad$ Second quartile & 0.23 & 0.19 & -0.00 \\
$\quad$ Third quartile & 0.22 & 0.22 & $-0.04^{* *}$ \\
$\quad$ Fourth quartile & 0.17 & 0.21 & 0.01 \\
$\quad$ Missing & 0.20 & 0.19 & $0.10^{* *}$ \\
Household size & 4.16 & 4.06 & $-0.05^{* * *}$ \\
Regional characteristics: & & & $0.87^{* * *}$ \\
Slot-child-ratio in 1998 & 0.73 & 0.78 & $-0.58^{* * *}$ \\
Conservative vote share & 45.68 & 44.80 & 4,579 \\
Female employment share & 41.30 & 41.87 & 3,254 \\
\hline$N$ & 1,325 & & \\
\hline
\end{tabular}

Note: This table depicts summary statistics. Panel A shows mean differences of the outcome variables (Big Five personality traits) measured at age 15 in the NEPS by treatment status, i.e. compares adolescents who enter childcare at age three (treatment group) to those entering childcare approximately one year later at age four (control group). Panel B shows mean differences of the included control variables. Source: NEPS Data, Data Version SC4: 7.0.0 remote access, RDC of the Federal Statistical Office and the Statistical Offices of the Länder on the county level, statistics of children and youth welfare (Kinder- und Jugendhilfestatistik) for 1998, and INKAR data for 1998 (German Federal Office for Building and Regional Planning, 2018), own calculations, significance level: ${ }^{*} p<0.10 ;{ }^{* *} p<0.05$; *** $p<0.01$. 
Table 2: Summary statistics of personality traits in adolescence (NEPS)

\begin{tabular}{lcccc}
\hline Variable & Mean & Std. Dev. & Min. & Max. \\
\hline Personality traits in the NEPS & 3.49 & 0.97 & 1 & 5 \\
Openness & 3.15 & 0.87 & 1 & 5 \\
Conscientiousness & 3.44 & 0.88 & 1 & 5 \\
Extroversion & 3.47 & 0.67 & 1 & 5 \\
Agreeableness & 2.76 & 0.85 & 1 & 5 \\
Neuroticism & \multicolumn{5}{c}{4,579} \\
$N$ &
\end{tabular}

Notes: This table shows summary statistics of adolescents' personality traits at age 15 in the NEPS. The scores of the personality traits range from 1 (disagree strongly) to 5 (strongly agree) in the NEPS. A higher value represents a higher score on the respective personality dimension. Source: NEPS Data, Data Version SC4: 7.0.0 remote access, own calculations.

Table 3: First stage estimation of instrument "slot-child-ratio" on one additional year of childcare (NEPS)

\begin{tabular}{lcccc}
\hline & \multicolumn{4}{c}{ First stage IV estimation } \\
\cline { 2 - 5 } & $(1)$ & $(2)$ & $(3)$ & $(4)$ \\
\hline Slot-child-ratio 1998 & $0.854^{* * *}$ & $0.867^{* * *}$ & $0.867^{* * *}$ & $0.931^{* * *}$ \\
& $(0.078)$ & $(0.077)$ & $(0.076)$ & $(0.084)$ \\
\hline Birth month fixed effects & Yes & Yes & Yes & Yes \\
Individual controls & No & Yes & Yes & Yes \\
Full controls & No & No & Yes & Yes \\
Regional controls & No & No & No & Yes \\
\hline First-stage F-test & 120.22 & 125.75 & 129.57 & 142.94 \\
$N$ & 4,579 & 4,579 & 4,579 & 4,579 \\
$R^{2}$ & 0.042 & 0.077 & 0.084 & 0.100 \\
\hline
\end{tabular}

Notes: The table shows first stages estimates where the county level slot-child-ratio for 1998 is used as an instrument on one additional year of childcare. Standard errors are clustered at the county level and are given in parentheses. The sample for the models in columns (1) through (4) consists of all children who enter childcare within two months of the start of the school year in which they turn three (treatment group) or four (control group). Individual controls include migration background, mother's age at birth, sex of the child, a dummy for being a single parent and dummies for mother's years of education. Full controls further include mother's employment status, dummies for household income and size. Regional controls include quintile dummies for the county population density, unemployment rate, share of foreigners, per capita GDP, as well as county level conservative vote share, and female employment share. Source: NEPS Data, Data Version SC4: 7.0.0 remote access, RDC of the Federal Statistical Office and the Statistical Offices of the Länder on the county level, statistics of children and youth welfare (Kinder- und Jugendhilfestatistik) for 1998 and INKAR data for 1998 (German Federal Office for Building and Regional Planning, 2018), own calculations, significance level: * $p<0.10 ; * * p<0.05 ;{ }^{* * *} p<0.01$. 
Table 4: Estimation of one additional year of childcare on adolescents' personality traits (NEPS)

\begin{tabular}{|c|c|c|c|c|c|c|c|c|}
\hline & \multicolumn{4}{|c|}{ OLS } & \multicolumn{4}{|c|}{ 2SLS } \\
\hline & (1) & $(2)$ & $(3)$ & (4) & $(5)$ & (6) & $(7)$ & $(8)$ \\
\hline Openness & $\begin{array}{c}0.071^{* *} \\
(0.030)\end{array}$ & $\begin{array}{c}0.060^{* *} \\
(0.030)\end{array}$ & $\begin{array}{c}0.056^{*} \\
(0.031)\end{array}$ & $\begin{array}{l}0.059^{*} \\
(0.031)\end{array}$ & $\begin{array}{c}0.025 \\
(0.170)\end{array}$ & $\begin{array}{l}-0.040 \\
(0.168)\end{array}$ & $\begin{array}{l}-0.020 \\
(0.165)\end{array}$ & $\begin{array}{c}0.026 \\
(0.173)\end{array}$ \\
\hline Conscientiousness & $\begin{array}{c}-0.093^{* * *} \\
(0.033)\end{array}$ & $\begin{array}{c}-0.092^{* * *} \\
(0.033)\end{array}$ & $\begin{array}{c}-0.088^{* * * *} \\
(0.033)\end{array}$ & $\begin{array}{c}-0.088^{* * *} \\
(0.033)\end{array}$ & $\begin{array}{c}0.261 \\
(0.172)\end{array}$ & $\begin{array}{l}0.273^{*} \\
(0.166)\end{array}$ & $\begin{array}{c}0.269 \\
(0.164)\end{array}$ & $\begin{array}{c}0.251 \\
(0.170)\end{array}$ \\
\hline Extroversion & $\begin{array}{c}0.124^{* * *} \\
(0.032)\end{array}$ & $\begin{array}{c}0.118^{* * *} \\
(0.031)\end{array}$ & $\begin{array}{c}0.108^{* * *} \\
(0.032)\end{array}$ & $\begin{array}{c}0.107^{* * *} \\
(0.032)\end{array}$ & $\begin{array}{c}0.312^{* *} \\
(0.156)\end{array}$ & $\begin{array}{c}0.308^{* *} \\
(0.151)\end{array}$ & $\begin{array}{c}0.298^{* *} \\
(0.147)\end{array}$ & $\begin{array}{c}0.367^{* *} \\
(0.171)\end{array}$ \\
\hline Agreeableness & $\begin{array}{c}-0.033 \\
(0.034)\end{array}$ & $\begin{array}{l}-0.032 \\
(0.034)\end{array}$ & $\begin{array}{l}-0.029 \\
(0.034)\end{array}$ & $\begin{array}{c}-0.040 \\
(0.034)\end{array}$ & $\begin{array}{c}0.312 \\
(0.194)\end{array}$ & $\begin{array}{c}0.290 \\
(0.192)\end{array}$ & $\begin{array}{c}0.290 \\
(0.191)\end{array}$ & $\begin{array}{c}-0.014 \\
(0.192)\end{array}$ \\
\hline Neuroticism & $\begin{array}{l}-0.011 \\
(0.034)\end{array}$ & $\begin{array}{l}-0.010 \\
(0.035)\end{array}$ & $\begin{array}{l}-0.000 \\
(0.035)\end{array}$ & $\begin{array}{c}0.011 \\
(0.035)\end{array}$ & $\begin{array}{c}0.006 \\
(0.176)\end{array}$ & $\begin{array}{c}-0.001 \\
(0.174)\end{array}$ & $\begin{array}{l}-0.007 \\
(0.174)\end{array}$ & $\begin{array}{l}-0.026 \\
(0.172)\end{array}$ \\
\hline Birth month FE & Yes & Yes & Yes & Yes & Yes & Yes & Yes & Yes \\
\hline Individual controls & No & Yes & Yes & Yes & No & Yes & Yes & Yes \\
\hline Full controls & No & No & Yes & Yes & No & No & Yes & Yes \\
\hline Regional controls & No & No & No & Yes & No & No & No & Yes \\
\hline$N$ & 4,579 & 4,579 & 4,579 & 4,579 & 4,579 & 4,579 & 4,579 & 4,579 \\
\hline
\end{tabular}

Notes: The table shows OLS and 2SLS estimates where the county-level slot-child-ratio for 1998 is used as an instrument on one additional year of childcare. Standard errors are clustered at the county level and are given in parentheses. The sample for the models in columns (1) through (6) consists of all children who enter childcare within 2 months of the start of the school year in which they turn three (treatment group) or four (control group) in western Germany. Individual controls include migration background, mother's age at birth, sex of the child, a dummy for being a single parent and dummies for mother's years of education. Full controls include mother's employment status, dummies for household income and size. Regional controls include quintile dummies for the county population density, unemployment rate, share of foreigners, per capita GDP, as well as county level conservative vote share, and female employment share. Source: NEPS Data, Data Version SC4: 7.0.0 remote access, RDC of the Federal Statistical Office and the Statistical Offices of the Länder on the county level, statistics of children and youth welfare (Kinder- und Jugendhilfestatistik) for 1998 and INKAR data for 1998 (German Federal Office for Building and Regional Planning, 2018), own calculations, significance level: ${ }^{*} p<0.10{ }^{* *} p<0.05 ;{ }^{* * *} p<0.01$.

Table 5: Complier characteristics for slot-child-ratio instrument (NEPS)

\begin{tabular}{lccr}
\hline & $P\left(X_{i}=1\right)$ & $P\left(X_{i}=1 \mid C_{1 i}>C_{0 i}\right)$ & $\frac{P\left(X_{i}=1\right) \mid C_{1 i}>C}{P\left(X_{i}=1\right)}$ \\
\hline Complier characteristics & & & \\
Migration background & 0.253 & 0.248 & 0.977 \\
Single parent household & 0.085 & 0.097 & 1.140 \\
Mother working at age 15 of child & 0.794 & 0.790 & 0.994 \\
$\begin{array}{l}\text { Mother has no postsecondary } \\
\text { educational qualification }\end{array}$ & 0.105 & 0.113 & 1.078
\end{tabular}

Notes: The table reports an analysis of complier characteristics for the slot-child-ratio instrument. $Z$ is defined as a binary variable taking the value 0 if the slot-child-ratio is below the $33^{r d}$ slot-child-ratio percentile and the value 1 if it is above the $66^{\text {th }}$ percentile. $C_{1 i}$ indicates early childcare entry when $Z=1$ and $C_{0 i}$ when $Z=1$. The ratios in column 3 give the relative likelihood that compliers have the characteristics indicated on the left hand side. Source: NEPS Data, Data Version SC4: 7.0.0 remote access, RDC of the Federal Statistical Office and the Statistical Offices of the Länder on the county level, statistics of children and youth welfare (Kinderund Jugendhilfestatistik) for 1998 and INKAR data for 1998 (German Federal Office for Building and Regional Planning, 2018), own calculations, significance level: ${ }^{*} p<0.10{ }^{* *} p<0.05 ;{ }^{* * *} p<0.01$. 
Table 6: Estimation of one additional year of childcare on adolescents' personality traits (SOEP)

\begin{tabular}{|c|c|c|c|c|c|c|}
\hline & \multicolumn{3}{|c|}{ OLS } & \multicolumn{3}{|c|}{$2 \mathrm{SLS}$} \\
\hline & (1) & $(2)$ & $(3)$ & $(4)$ & $(5)$ & (6) \\
\hline Openness & $\begin{array}{c}0.272^{* * * *} \\
(0.097)\end{array}$ & $\begin{array}{c}0.263^{* * *} \\
(0.091)\end{array}$ & $\begin{array}{c}0.290^{* * *} \\
(0.097)\end{array}$ & $\begin{array}{c}0.260 \\
(0.282)\end{array}$ & $\begin{array}{c}0.292 \\
(0.275)\end{array}$ & $\begin{array}{c}0.324 \\
(0.259)\end{array}$ \\
\hline Conscientiousness & $\begin{array}{c}0.117 \\
(0.095)\end{array}$ & $\begin{array}{c}0.124 \\
(0.090)\end{array}$ & $\begin{array}{c}0.106 \\
(0.092)\end{array}$ & $\begin{array}{c}0.302 \\
(0.285)\end{array}$ & $\begin{array}{c}0.310 \\
(0.287)\end{array}$ & $\begin{array}{c}0.167 \\
(0.288)\end{array}$ \\
\hline Extroversion & $\begin{array}{c}0.186^{* *} \\
(0.083)\end{array}$ & $\begin{array}{c}0.180^{* *} \\
(0.080)\end{array}$ & $\begin{array}{c}0.212^{* * *} \\
(0.080)\end{array}$ & $\begin{array}{c}0.614^{* *} \\
(0.278)\end{array}$ & $\begin{array}{c}0.606^{* *} \\
(0.272)\end{array}$ & $\begin{array}{c}0.594^{* *} \\
(0.264)\end{array}$ \\
\hline Agreeableness & $\begin{array}{l}-0.136 \\
(0.093)\end{array}$ & $\begin{array}{c}-0.130 \\
(0.090)\end{array}$ & $\begin{array}{c}-0.171^{*} \\
(0.094)\end{array}$ & $\begin{array}{c}0.057 \\
(0.300)\end{array}$ & $\begin{array}{c}0.044 \\
(0.299)\end{array}$ & $\begin{array}{c}0.054 \\
(0.326)\end{array}$ \\
\hline Neuroticism & $\begin{array}{c}-0.216^{* *} \\
(0.087)\end{array}$ & $\begin{array}{c}-0.211^{* *} \\
(0.088)\end{array}$ & $\begin{array}{l}-0.186^{*} \\
(0.095)\end{array}$ & $\begin{array}{l}-0.493 \\
(0.335)\end{array}$ & $\begin{array}{l}-0.455 \\
(0.331)\end{array}$ & $\begin{array}{l}-0.623^{*} \\
(0.323)\end{array}$ \\
\hline Full controls & Yes & Yes & Yes & Yes & Yes & Yes \\
\hline Parents' personality controls & No & Yes & Yes & No & Yes & Yes \\
\hline Regional controls & No & No & Yes & No & No & Yes \\
\hline$N$ & 631 & 631 & 631 & 631 & 631 & 631 \\
\hline
\end{tabular}

Notes: The table shows OLS and 2SLS estimates where the county-level slot-child-ratio from the year 1994 (for birth cohorts 1990-1994) and from 1998 (for birth cohorts 1995-1998) is used as instrument for one additional year of childcare on the respective personality trait. Standard errors are clustered at the county level and are given in parentheses. The sample for models in columns (1) through (6) consists of all children who enter childcare in the year that they turn three (treatment group) or four (control group) in western Germany. Full controls include the child's gender, migration background as well as dummies for the children's birth year and month, the mother's age at birth, a dummy for being a single parent, dummies for her education background and employment status, dummies for household income and size. Parents' personality controls comprise Big Five personality traits of mothers and (social) fathers. Regional controls include the county's population density, unemployment rate, female employment rate, share of foreigners, per capita GDP, and conservative vote share. Source: SOEP v32 (2007-2015, birth cohorts 1990-1998), RDC of the Federal Statistical Office and the Statistical Offices of the Länder on the county level, statistics of children and youth welfare (Kinder- und Jugendhilfestatistik) for 1998 and INKAR data for 1998 (German Federal Office for Building and Regional Planning, 2018), own calculations, significance level: ${ }^{*} p<0.10 ;{ }^{* *} p<0.05 ;{ }^{* * *} p<0.01$. 
Table 7: Robustness of 2SLS estimation of one additional year of childcare on adolescents' personality traits (NEPS)

\begin{tabular}{lcccc}
\hline & \multicolumn{4}{c}{ 2SLS } \\
\cline { 2 - 5 } & $(1)$ & $(2)$ & $(3)$ & $(4)$ \\
\hline Openness & 0.057 & -0.016 & 0.004 & 0.136 \\
Conscientiousness & $(0.182)$ & $(0.179)$ & $(0.174)$ & $(0.171)$ \\
& 0.279 & 0.291 & 0.295 & 0.187 \\
Extraversion & $(0.199)$ & $(0.191)$ & $(0.189)$ & $(0.183)$ \\
& $0.394^{* *}$ & $0.382^{* *}$ & $0.359^{* *}$ & $0.327^{* *}$ \\
Agreeableness & $(0.162)$ & $(0.160)$ & $(0.157)$ & $(0.160)$ \\
& $0.579^{* * *}$ & $0.532^{* *}$ & $0.550^{* * *}$ & 0.168 \\
Neuroticism & $(0.214)$ & $(0.209)$ & $(0.208)$ & $(0.188)$ \\
& -0.054 & -0.075 & -0.061 & -0.110 \\
Birth month fixed effects & $(0.186)$ & $(0.183)$ & $(0.184)$ & $(0.161)$ \\
Individual controls & Yes & Yes & Yes & Yes \\
Full controls & No & Yes & Yes & Yes \\
Regional controls & No & No & Yes & Yes \\
\hline$N$ & 4,505 & 4,505 & 4,505 & Yes \\
\hline
\end{tabular}

Notes: The table shows 2SLS estimates where the slot-child-ratio for 1994 is used as an instrument on one more year of childcare on the respective personality trait at age 15. Standard errors are clustered at the county level are given in parentheses. The sample for the models in columns (1) through (3) consists of all children who enter childcare within 2 months of the start of the school year in the year that they turn three (treatment group) or four (control group) in western Germany. Individual controls include migration background, mother's age at birth, sex of the child, a dummy for being a single parent and dummies for mother's years of education. Full controls include mother's employment status, dummies for household income and size. Regional controls include quintile dummies for the county population density, unemployment rate, share of foreigners, per capita GDP, as well as county level conservative vote share, and female employment share. Source: NEPS Data, Data Version SC4: 7.0.0 remote access, RDC of the Federal Statistical Office and the Statistical Offices of the Länder on the county level, statistics of children and youth welfare (Kinderund Jugendhilfestatistik) for 1998 and INKAR data for 1998 (German Federal Office for Building and Regional Planning, 2018), own calculations, significance level: ${ }^{*} p<0.10 ;{ }^{* *} p<0.05 ;{ }^{* * *} p<0.01$. 
Table 8: Estimation of one additional year of childcare on pre-determined outcomes (NEPS)

\begin{tabular}{|c|c|c|c|c|c|c|}
\hline & \multicolumn{2}{|c|}{ Height at adolescence } & \multicolumn{2}{|c|}{ Low birthweight $(<2,500 \mathrm{~g})$} & \multicolumn{2}{|c|}{ Premature birth } \\
\hline & OLS & 2SLS & OLS & $2 \mathrm{SLS}$ & OLS & 2SLS \\
\hline Early childcare entry & $\begin{array}{c}-0.600 \\
(0.365)\end{array}$ & $\begin{array}{c}-1.826 \\
(1.770)\end{array}$ & $\begin{array}{c}-0.015 \\
(0.012)\end{array}$ & $\begin{array}{c}0.007 \\
(0.040)\end{array}$ & $\begin{array}{c}-0.012 \\
(0.014)\end{array}$ & $\begin{array}{c}-0.010 \\
(0.048)\end{array}$ \\
\hline$N$ & 4,164 & 4,164 & 1,855 & 1,855 & 1,928 & 1,928 \\
\hline
\end{tabular}

Notes: The table shows OLS and 2SLS estimates where the county-level slot-child-ratio for 1998 is used as an instrument on one additional year of childcare. Standard errors are clustered at the county level and are given in parentheses. The sample for the models in columns (1) through (4) consists of all children who enter childcare within 2 months of the start of the school year in which they turn three (treatment group) or four (control group) in western Germany. The displayed regression coefficient includes all controls from our preferred specification from Table 4, including migration background, mother's age at birth, sex of the child, a dummy for being a single parent,dummies for mother's years of education as individual controls, as well as mother's employment status, dummies for household income and size, and regional controls such as quintile dummies for the county population density, unemployment rate, share of foreigners, per capita GDP, conservative vote share, and female employment share. Source: NEPS Data, Data Version SC4: 7.0.0 remote access, RDC of the Federal Statistical Office and the Statistical Offices of the Länder on the county level, statistics of children and youth welfare (Kinder- und Jugendhilfestatistik) for 1998 and INKAR data for 1998 (German Federal Office for Building and Regional Planning, 2018), own calculations, significance level: ${ }^{*} p<0.10 ;{ }^{* *} p<0.05 ;{ }^{* * *} p<0.01$. 
Figure 4: County level maps of different indicators related to demand and supply of childcare
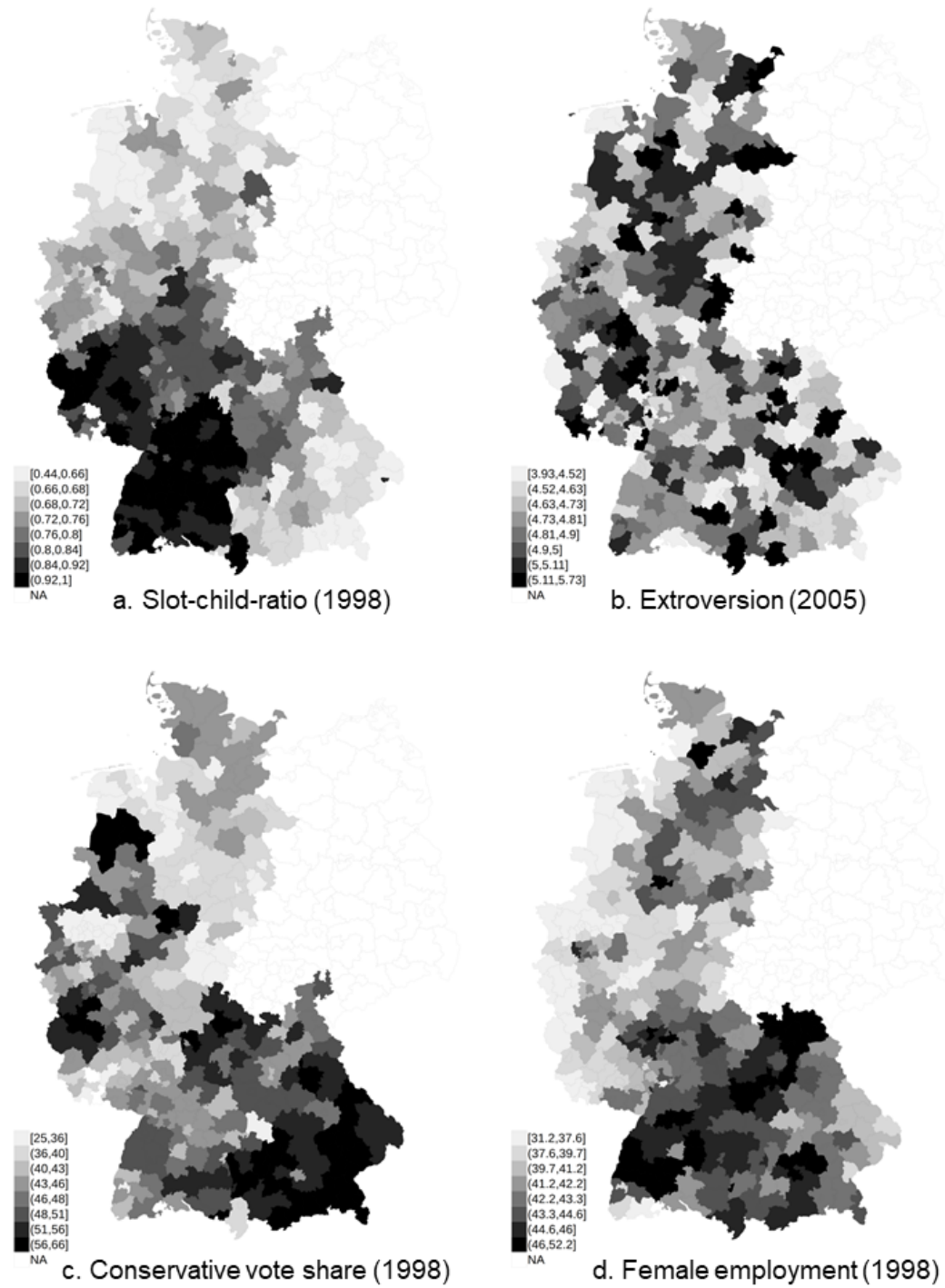

Notes: This figure shows four maps. On the upper left-hand side (a) the slot-child-ratio of each county in western Germany measured in the year 1998 is depicted from Figure 2, showing a very heterogeneous level of childcare provision in 1998. The upper right-hand side (b) shows the aggregated personality trait extroversion of adults participating in the 2005 SOEP wave using county level data of 20,000 observations. In the lower left-hand side (c), the conservative vote share in 1998 is depicted, showing also heterogeneous levels among counties. The lower right-hand side (d) provides the female employment rate in 1998 in western Germany giving another indication for differences in among counties. Both figures in the lower part give some indication of factors related to the demand side of childcare in the late 1990s. Source: SOEP v32 (wave 2005), RDC of the Federal Statistical Office and the Statistical Offices of the Länder on the county level, statistics of children and youth welfare (Kinder- und Jugendhilfestatistik) for 1998, and INKAR data for 1998 (German Federal Office for Building and Regional Planning, 2018), own graphical display. 


\section{Appendix}

Figure A.1: Internal migration in Germany per 10,000 people (1996)

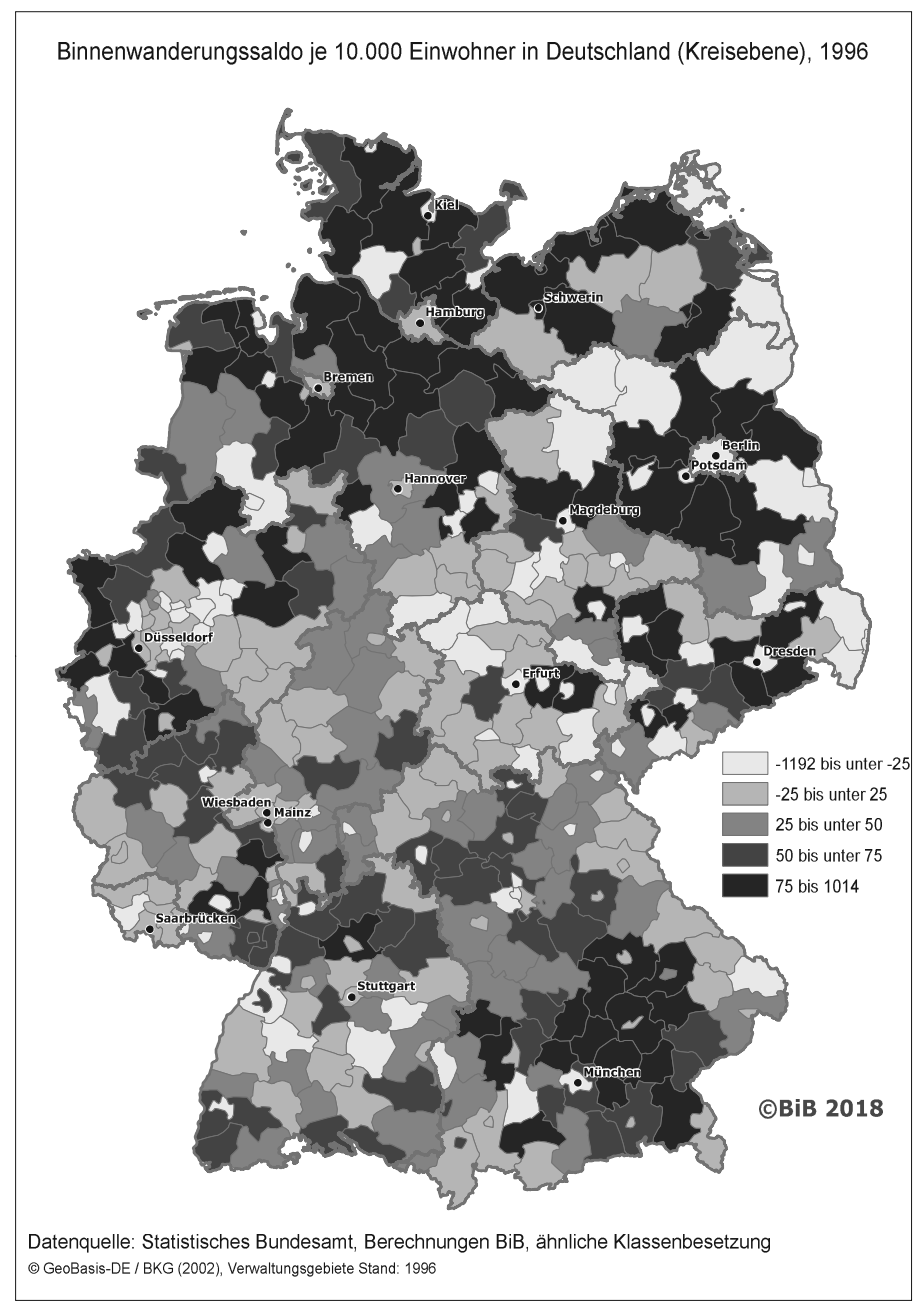

Notes: This figure shows the net internal migration balance measuring the in- and outflow on the local level. Overall, internal migration numbers are very low. Counties shaded in black represent counties with a positive migration balance, lighter areas stand for counties with more people emigrating than migrating. Source: German Federal Institute for Population Research (2018) 
Table A.1: Definition of personality traits

\begin{tabular}{ll}
\hline Personality Trait & Definition \\
\hline Openness (to Experience) & $\begin{array}{l}\text { Tendency to be open to new cultural } \\
\text { or intellectual experiences } \\
\text { Tendency to be organized, responsible, } \\
\text { Conscientiousness }\end{array}$ \\
$\begin{array}{l}\text { Refers to sociableness, activeness, assertiveness, } \\
\text { tendency to orientate one's energies to } \\
\text { the outer world of people }\end{array}$ \\
Tendency to act in cooperation, an unselfish \\
Agreeableness & $\begin{array}{l}\text { manner, and flexibility } \\
\text { Neuroticism (Emotional stability) }\end{array}$ \\
& $\begin{array}{l}\text { Different facets of anxiety, insecurity, } \\
\text { impulsiveness, and vulnerability }\end{array}$ \\
\hline
\end{tabular}

Source: Information taken from Almlund et al. (2011).

Table A.2: Big Five personality traits inventory (NEPS and SOEP)

\section{Panel A: NEPS items}

I am a person who...:

Openness

Conscientiousness

has few artistic interests (-), has an active imagination, tends to be lazy (-), does a thorough job

Extroversion

is outgoing, sociable, is reserved (-)

Agreeableness

tends to find fault with others $(-)$, is generally trusting

Neuroticism

gets nervous easily, is relaxed/handles stress well (-)

\section{Panel B: SOEP items}

Openness

I am a person who...:

Conscientiousness

has new ideas, values cultural experience, has an active imagination, is inquisitive

Extroversion works thoroughly, is lazy (-), handles her tasks efficiently

Agreeableness is communicative, mixes well, is reserved/guarded (-)

Neuroticism sometimes manhandles others (-), forgives, is considerate worries a lot, is easily flustered, is relaxed/deals well with stress (-)

Source: For Panel A information is taken from Rammstedt and John (2007) and for Panel B from the SOEP youth questionnaire. The (-) sign indicates items that are reversely coded. 
Table A.3: Summary statistics of personality traits in adolescence (SOEP)

\begin{tabular}{lcccc}
\hline Variable & Mean & Std. Dev. & Min. & Max. \\
\hline Openness & 4.78 & 0.93 & 2 & 7 \\
Conscientiousness & 4.91 & 1.02 & 1.67 & 7 \\
Extroversion & 4.90 & 1.20 & 1.33 & 7 \\
Agreeableness & 5.40 & 0.90 & 2.33 & 7 \\
Neuroticism & 3.95 & 1.17 & 1 & 7 \\
\hline$N$ & \multicolumn{3}{c}{631} \\
\hline
\end{tabular}

Notes: This table shows summary statistics of adolescents' personality traits at age 17 in the SOEP. The scores of the personality traits range from 1 (do not agree) to 7 (completely agree) in the SOEP. A higher value represents a higher score on the respective personality dimension. Source: SOEP v32 (2007-2015, birth cohorts 1990-1998), own calculations.

Table A.4: First stage estimation of instrument "slot-child-ratio" on one additional year of childcare (SOEP)

\begin{tabular}{|c|c|c|c|}
\hline & \multicolumn{3}{|c|}{ First stage estimation } \\
\hline & (1) & $(2)$ & $(3)$ \\
\hline Slot-child-ratio & & & \\
\hline \multirow{3}{*}{$\begin{array}{l}\text { Full controls } \\
\text { Parents' personality controls } \\
\text { Regional controls }\end{array}$} & Yes & Yes & Yes \\
\hline & No & Yes & Yes \\
\hline & No & No & Yes \\
\hline \multirow{3}{*}{$\begin{array}{l}\text { First-stage F-test } \\
N \\
R^{2}\end{array}$} & 17.495 & 30.284 & 14.952 \\
\hline & 631 & 631 & 631 \\
\hline & 0.236 & 0.229 & 0.277 \\
\hline \multicolumn{4}{|c|}{$\begin{array}{l}\text { Notes: The table shows first stage estimates of the instrument slot- } \\
\text { child-ratio on one more year of childcare. Birth cohorts 1990-1994 are } \\
\text { matched to the regional slot-child-ratio for the year 1994, and birth } \\
\text { cohorts 1995-1998 to the slot-child-ratio for 1998. Standard errors are } \\
\text { clustered at the county level and are given in parentheses. The sample } \\
\text { for models in columns (1) through (3) consists of all children who enter } \\
\text { childcare in the year that they turn three (treatment group) or four } \\
\text { (control group) in western Germany. Full controls include the child's } \\
\text { gender, migration background as well as dummies for the children's birth } \\
\text { year and month, the mother's age at birth, a dummy for being a single } \\
\text { parent, dummies for her education background and employment status, } \\
\text { dummies for household income and size. Parents' personality controls } \\
\text { comprise Big Five personality traits of mothers and (social) fathers. } \\
\text { Regional controls include the county's population density, unemployment } \\
\text { rate, female employment rate, share of foreigners, per capita GDP, and } \\
\text { conservative vote share. Source: SOEP v32 (2007-2015, birth cohorts } \\
\text { 1990-1998), RDC of the Federal Statistical Office and the Statistical } \\
\text { Offices of the Länder on the county level, statistics of children and youth } \\
\text { welfare (Kinder- und Jugendhilfestatistik) for } 1994 \text { and } 1998 \text {, and INKAR } \\
\text { data for } 1998 \text { (German Federal Office for Building and Regional Planning, } \\
2018 \text {, own calculations, significance level: } * p<0.10 ; * * p<0.05 ; * * * \\
p<0.01 \text {. }\end{array}$} \\
\hline
\end{tabular}


Table A.5: Summary statistics of additional child characteristics and regional characteristics by treatment status (SOEP)

\begin{tabular}{|c|c|c|c|}
\hline & \multicolumn{2}{|c|}{ Mean } & \multirow[t]{2}{*}{ Mean differences } \\
\hline & Control group & Treatment group & \\
\hline \multicolumn{4}{|l|}{ Child characteristics: } \\
\hline Male & 0.52 & 0.45 & 0.08 \\
\hline \multirow{2}{*}{\multicolumn{4}{|c|}{ Birthorder: }} \\
\hline & & & \\
\hline First-Born Child & 0.40 & 0.33 & 0.07 \\
\hline Second-Born Child & 0.32 & 0.39 & -0.07 \\
\hline Third-Born Child & 0.13 & 0.12 & 0.01 \\
\hline Fourth-Born Child & 0.05 & 0.04 & 0.01 \\
\hline Fifth- or Higher-Born Child & 0.03 & 0.01 & $0.02 *$ \\
\hline Missing & 0.06 & 0.10 & -0.04 \\
\hline \multicolumn{4}{|l|}{ Maternal characteristics: } \\
\hline \multicolumn{4}{|l|}{ Maternal Employment: } \\
\hline Full Time & 0.01 & 0.06 & $-0.05^{* * *}$ \\
\hline Part Time & 0.23 & 0.32 & $-0.10^{* *}$ \\
\hline Not Working & 0.69 & 0.51 & $0.18^{* * *}$ \\
\hline Missing & 0.07 & 0.11 & -0.04 \\
\hline \multicolumn{4}{|l|}{ Maternal Education: } \\
\hline Less than High School & 0.22 & 0.17 & 0.04 \\
\hline High School & 0.54 & 0.54 & 0.00 \\
\hline More than High School & 0.16 & 0.16 & -0.01 \\
\hline Missing & 0.09 & 0.13 & -0.04 \\
\hline Single parent & 0.05 & 0.06 & -0.01 \\
\hline Mother's age at birth & 28.70 & 29.43 & -0.73 \\
\hline \multicolumn{4}{|l|}{ Household characteristics: } \\
\hline \multicolumn{4}{|l|}{ Household Income: } \\
\hline First Quartile & 0.27 & 0.14 & $0.12^{* * *}$ \\
\hline Second Quartile & 0.28 & 0.26 & 0.02 \\
\hline Third Quartile & 0.21 & 0.21 & 0.00 \\
\hline Fourth Quartile & 0.17 & 0.26 & $-0.09^{* *}$ \\
\hline Missing & 0.08 & 0.13 & $-0.05^{*}$ \\
\hline \multicolumn{4}{|l|}{ Number of Children in Household: } \\
\hline One Child & 0.28 & 0.26 & 0.03 \\
\hline Two Children & 0.40 & 0.48 & $-0.08^{*}$ \\
\hline Three Children & 0.16 & 0.11 & $0.06^{*}$ \\
\hline Four or More Children & 0.08 & 0.05 & 0.03 \\
\hline Missing & 0.07 & 0.11 & -0.04 \\
\hline \multicolumn{4}{|l|}{ Regional characteristics: } \\
\hline Slot-child-ratio & 0.64 & 0.72 & $-0.08^{* * *}$ \\
\hline Population density (in people per $\mathrm{km}^{2}$ ) & 783.02 & 811.97 & -28.95 \\
\hline Unemployment rate & 8.89 & 8.35 & $0.53^{*}$ \\
\hline Share of foreigners & 9.73 & 10.31 & -0.57 \\
\hline Per capita GDP (in 1000 Euro) & 25.84 & 26.53 & -0.69 \\
\hline Conservative vote share & 44.34 & 43.57 & 0.78 \\
\hline Female employment share & 41.76 & 42.73 & $-0.97^{* *}$ \\
\hline Adult extroversion (SOEP 2005) & 4.78 & 4.82 & $-0.04^{*}$ \\
\hline$N$ & 263 & 368 & 631 \\
\hline
\end{tabular}

Notes: This table depicts additional summary statistics of the SOEP sample for adolescents who enter childcare in the year they either turn three (treatment group) or four (control group) in western Germany. Source: SOEP v32 (2007-2015, birth cohorts 1990-1998) and SOEP v32 (wave 2005), RDC of the Federal Statistical Office and the Statistical Offices of the Länder on the county level, statistics of children and youth welfare (Kinder- und Jugendhilfestatistik) for 1994 and 1998, and INKAR data for 1998 (German Federal Office for Building and Regional Planning, 2018), own calculations, significance level: ${ }^{*} p<0.10{ }^{* *} p<0.05$; ${ }^{* * *} p<0.01$. 
Table A.6: Estimation of one additional year of childcare on adolescents' personality traits (NEPS)

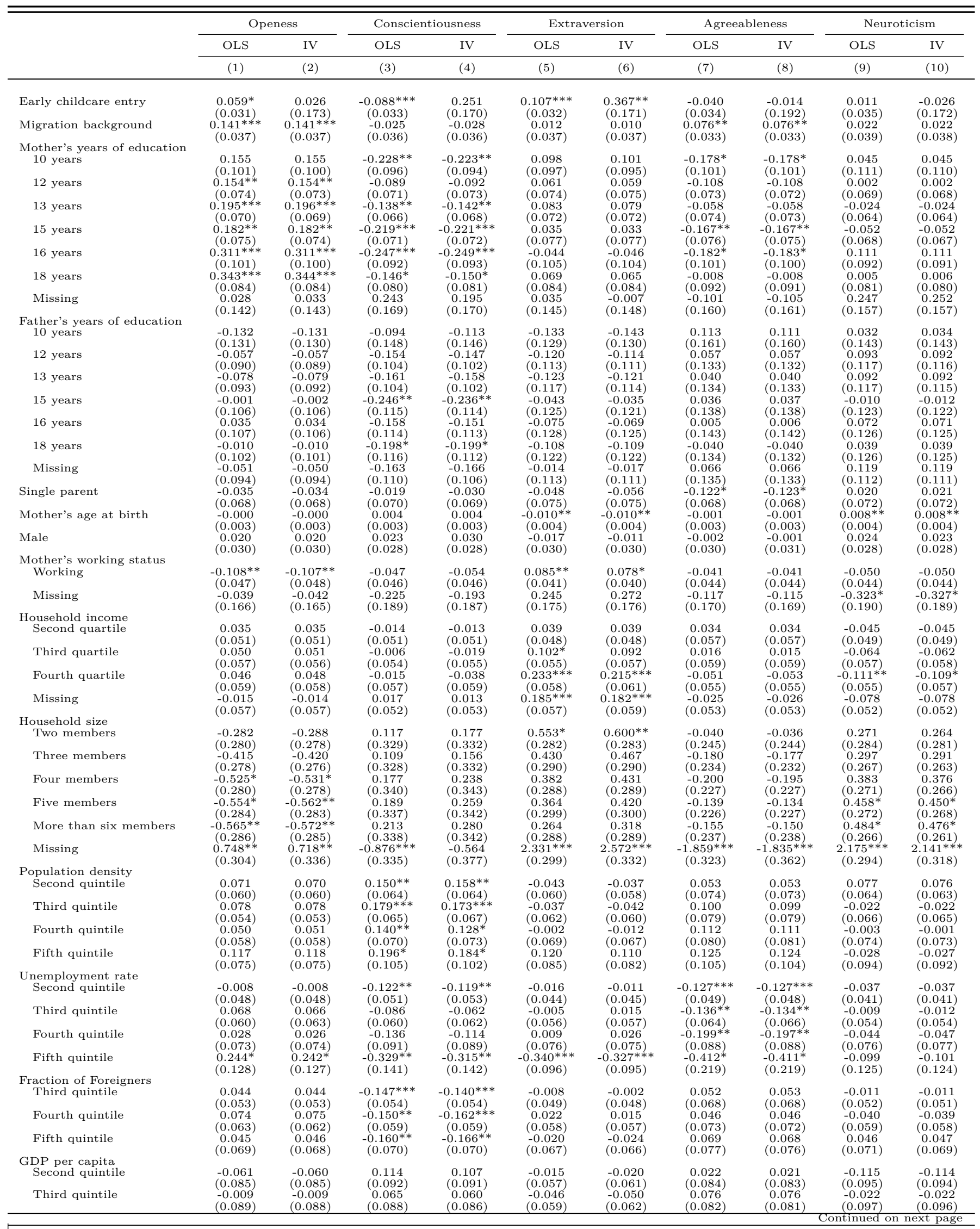


Table A.6 - continued from previous page

\begin{tabular}{|c|c|c|c|c|c|c|c|c|c|c|}
\hline & \multicolumn{2}{|c|}{ Openess } & \multicolumn{2}{|c|}{ Conscientiousness } & \multicolumn{2}{|c|}{ Extraversion } & \multicolumn{2}{|c|}{ Agreeableness } & \multicolumn{2}{|c|}{ Neuroticism } \\
\hline & OLS & IV & OLS & IV & OLS & IV & OLS & IV & OLS & IV \\
\hline & (1) & $(2)$ & $(3)$ & $(4)$ & $(5)$ & $(6)$ & $(7)$ & $(8)$ & $(9)$ & $(10)$ \\
\hline Fourth quintile & $\begin{array}{l}-0.079 \\
(0.086)\end{array}$ & -0.077 & $\begin{array}{l}0.098 \\
(0.088)\end{array}$ & $\begin{array}{c}0.074 \\
(0.088)\end{array}$ & $\begin{array}{l}-0.052 \\
(0.053)\end{array}$ & $\begin{array}{l}-0.070 \\
(0.060)\end{array}$ & $\begin{array}{l}0.011 \\
(0.082)\end{array}$ & $\begin{array}{l}0.009 \\
(0.082)\end{array}$ & $\begin{array}{l}-0.106 \\
(0.090)\end{array}$ & $\begin{array}{l}-0.103 \\
(0.090)\end{array}$ \\
\hline Fifth quintile & $-0.158^{*}$ & $-0.156^{*}$ & 0.089 & 0.074 & -0.084 & -0.095 & 0.027 & 0.026 & -0.119 & -0.118 \\
\hline & $(0.094)$ & $(0.093)$ & $(0.100)$ & $(0.098)$ & $(0.066)$ & $(0.069)$ & $(0.095)$ & $(0.095)$ & $(0.100)$ & $(0.099)$ \\
\hline Conservative vote share & -0.002 & -0.002 & 0.003 & 0.004 & 0.003 & 0.004 & 0.004 & 0.005 & 0.001 & 0.001 \\
\hline & $(0.003)$ & $(0.003)$ & $(0.003)$ & $(0.003)$ & $(0.003)$ & $(0.003)$ & $(0.003)$ & $(0.003)$ & $(0.002)$ & $(0.003)$ \\
\hline Female employment share & 0.008 & 0.008 & -0.008 & -0.011 & 0.011 & 0.009 & 0.004 & 0.004 & $-0.015^{* *}$ & $-0.015^{* *}$ \\
\hline $\begin{array}{l}\text { Birth month fixed effects } \\
N\end{array}$ & $\begin{array}{c}\text { Yes } \\
4,579\end{array}$ & $\begin{array}{c}\text { Yes } \\
4,579\end{array}$ & $\begin{array}{c}\text { Yes } \\
4,579\end{array}$ & $\begin{array}{c}\text { Yes } \\
4,579\end{array}$ & $\begin{array}{c}\text { Yes } \\
4,579\end{array}$ & $\begin{array}{c}\text { Yes } \\
4,579\end{array}$ & $\begin{array}{c}\text { Yes } \\
4,579\end{array}$ & $\begin{array}{c}\text { Yes } \\
4,579\end{array}$ & $\begin{array}{c}\text { Yes } \\
4,579\end{array}$ & $\begin{array}{c}\text { Yes } \\
4,579\end{array}$ \\
\hline
\end{tabular}

Notes: The table shows OLS and 2SLS estimates where the county-level slot-child-ratio for 1998 is used as an instrument on one additional year of childcare. Standard errors are clustered at the county level and are given in parentheses. The sample for the models in columns (1) through (10) consists of all children who enter childcare within two months of the start of the school year in which they turn three (treatment group) or four (control group) in western Germany. For regional variable "fraction of foreigners" the second quintile is the reference category, since there are no counties from the first quintile in our sample. Source: NEPS Data, Data Version SC4: 7.0.0 remote access, RDC of the Federal Statistical Office and the Statistical Offices of the Länder on the county level, statistics of children and youth welfare (Kinder- und Jugendhilfestatistik) for 1998 and INKAR data for 1998 (German Federal Office for Building and Regional Planning, 2018), own calculations, significance level: * $p<0.10$; ** $p<0.05 ; * * * p<0.01$. 